Portland State University

PDXScholar

\title{
Crime Risk near Reported Homeless Encampments: a Spatial Analysis
}

Kortney Lynn Russell

Portland State University

Follow this and additional works at: https://pdxscholar.library.pdx.edu/open_access_etds

Part of the Criminology Commons

Let us know how access to this document benefits you.

\section{Recommended Citation}

Russell, Kortney Lynn, "Crime Risk near Reported Homeless Encampments: a Spatial Analysis" (2020). Dissertations and Theses. Paper 5561.

https://doi.org/10.15760/etd.7435

This Thesis is brought to you for free and open access. It has been accepted for inclusion in Dissertations and Theses by an authorized administrator of PDXScholar. Please contact us if we can make this document more accessible: pdxscholar@pdx.edu. 
Crime Risk near Reported Homeless Encampments: A Spatial Analysis

\author{
by
}

Kortney Lynn Russell

A thesis submitted in partial fulfillment of the requirements for the degree of

\author{
Master of Science \\ in \\ Criminology and Criminal Justice
}

Thesis Committee:

Kathryn Wuschke, Chair

Mark Leymon

Mauri Matsuda

Portland State University 2020 
C 2020 Kortney Lynn Russell 


\begin{abstract}
Those experiencing homelessness face several challenges in contemporary society including a higher risk of victimization compared to the general population. In order to offer effective intervention to protect members of this population, understanding the spatial relationship between homeless camps and crime is imperative. To provide the foundation for a future risk assessment used to identify camps with a higher risk of nearby victimization, this study assessed crime concentration in relation to reported homeless camps in Portland, Oregon. Utilizing two publicly available data sources, this study conducted spatial analyses on voluntarily reported homeless camp data from October through December 2019 and reported crime data from 2019. To assess the potential risk of victimization across reported homeless encampments, crime concentration was measured within one-block of camp locations. Results indicated that crime was 2.9 times more concentrated within this area, as compared to the city. Further analyses indicated that all three categories, person, property, and society crime, were also concentrated near these camp locations. Taking a closer look at individual camps, spatial analyses were conducted to identify the camps at highest risk of victimization within each category. These high-risk camps had substantially higher concentrations of crime in proximity as compared to other camps, and to the city as a whole. At the base level, these findings suggest that risk of victimization should be considered as a factor when assessing the overall risks associated with areas near homeless encampments. Further, the City of Portland can utilize these research strategies to help prioritize communities for resource assistance, and other cities can adapt this model accordingly to best support the needs of members of this marginalized population.
\end{abstract}




\section{Acknowledgements}

Most importantly, to my advisor, Dr. Kathryn Wuschke, thank you for your patience and for introducing me to the world of crime mapping. Without your support and guidance, completing this thesis would not have been possible.

To my thesis committee, Dr. Mark Leymon and Dr. Mauri Matsuda, thank you for offering your unique perspectives and advice which helped me review my work more critically.

To my family (parents, siblings, cousins, aunts, uncles, and grandparents), thank you for your continuous support and your unconditional love. I would not have made it this far without you.

To the Griffith family, thank you for inspiring me with the support you give to the homeless community in Portland. The compassion you put into your work is truly admirable.

To Nataly, thank you for the laughs and for being the friend I never thought I would find in grad school.

To Alicia, Casey, and Jackie, thank you for always checking in on me. I will forever be grateful for your kindness and encouragement. 


\section{Table of Contents}

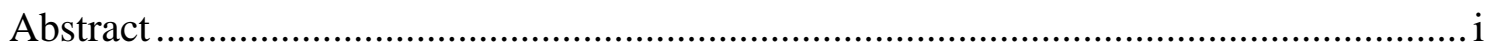

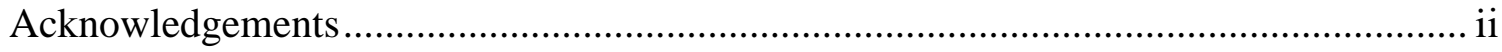

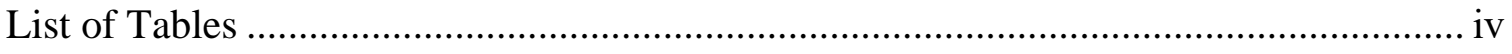

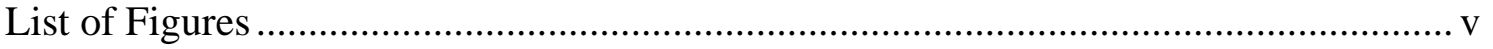

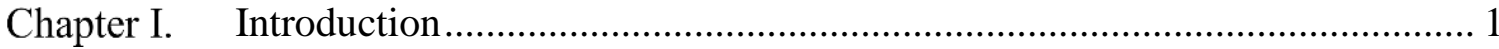

Chapter II. Literature Review......................................................................... 5

Spatial Theories of Crime …………………………............................................ 5

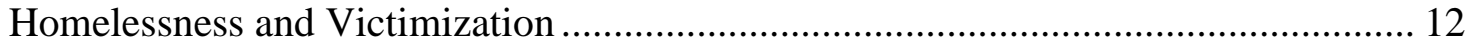

The Myth of Homelessness and Criminality ............................................................ 15

Spatial Context of Homelessness.......................................................................... 17

Homelessness in Portland: Considering the Local Context.......................................... 19

Research Contribution ……………………………………................................. 21

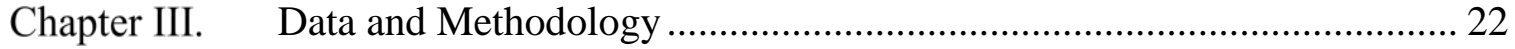

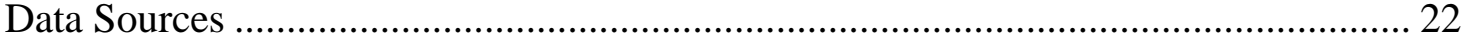

Homeless Camps ......................................................................................... 23

Crime

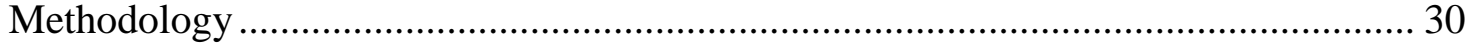

Chapter IV. Results ....................................................................................... 35

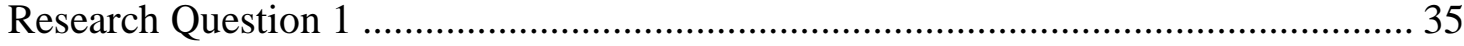

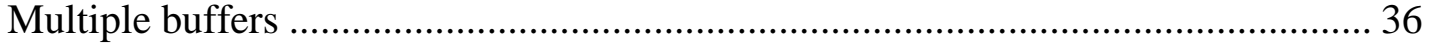

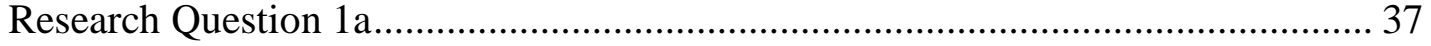

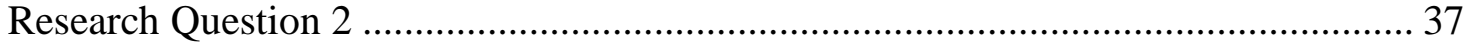

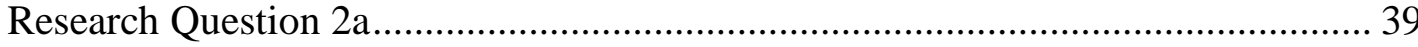

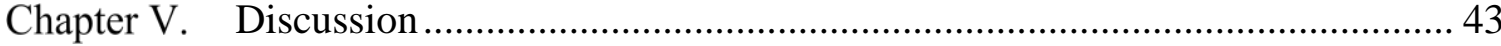

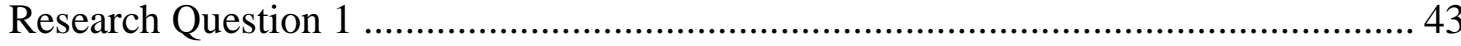

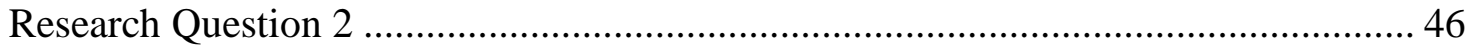

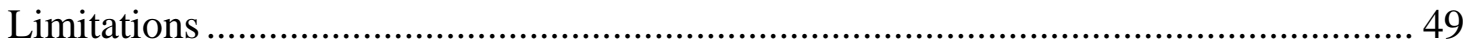

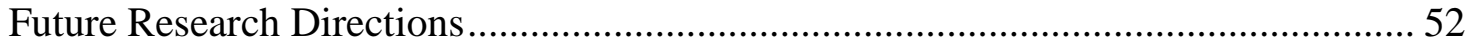

Chapter VI. Conclusion....................................................................................... 54

Chapter VII. References ................................................................................ 57 


\section{List of Tables}

Table 1. Crime Offense Incidents by Category: Portland, OR - 2019 (Portland Police Bureau, 2020b).

Table 2. Crime counts, area, and location quotient values as distance from camps increase

Table 3. Crime counts and location quotient values, separated by crime category

Table 4. Top 10 campsites associated with highest risk of victimization, based on count of crime events within 349 feet of site

Table 5. Top 10 campsites associated with highest risk of property crime victimization, based on count of crime events within 349 feet of site.

Table 6. Top 10 campsites associated with highest risk of society crime victimization, based on count of crime events within 349 feet of site.

Table 7. Top 10 campsites associated with highest risk of person crime victimization, based on count of crime events within 349 feet of site. 


\section{List of Figures}

Figure 1. Reported homeless camp locations in Portland, OR from October 2019 through December $2019(n=9,828)$

Figure 2. Spatial representation of crimes reported in Portland, OR in 2019 by crime

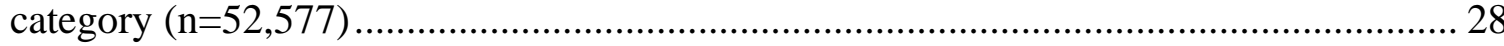

Figure 3. Multiple ring buffers in 349-foot intervals around reported homeless camp

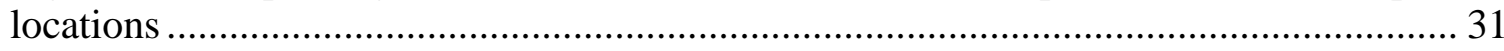

Figure 4. 349-foot undissolved buffers surrounding reported camp locations ................ 33 


\section{Chapter I. Introduction}

The systemic nature of homelessness has long been considered by researchers, policymakers, non-profit organizations, and law enforcement agencies. Regardless of the organizational perspective or approach, several key concerns surrounding homelessness remain consistent. On the individual level, those experiencing homelessness tend to face substantial social and physical barriers including disproportionately high rates of mental illness and other health problems (Maniglio, 2009; Nyamathi, Leake, \& Gelberg, 2000), higher likelihood of drug and alcohol addictions (Huntley, 2015), difficulty maintaining employment and social relationships (Henwood et al., 2010), and higher victimization rates than the general public (Edalati et al., 2017; Kim et al., 2010). At a societal level, public attitudes have shifted towards increasing compassion, including stronger support for the increased rights of individuals experiencing homelessness (Tsai et al., 2017).

From a criminological standpoint, the high rate of victimization found among homeless communities warrants further investigation. Several studies have contributed to this understanding through identifying relationships between crime and homeless status. One such study found that around 73.7 to $87.0 \%$ of the respective samples of individuals experiencing homelessness have been a victim of a crime at some point in their lives

(Roy et al., 2014). The prevalence of mental illness among the homeless community has been found to further increase the risk of victimization (Maniglio, 2008). As of 2010, four states have enacted laws classifying attacks on people experiencing homelessness as hate crimes (United States, 2011). The National Coalition for the Homeless has been documenting these attacks throughout the past 20 years, finding that yearly rates of 
crimes against homeless individuals tend to be significantly higher than hate crimes against other marginalized groups (Leomporra \& Hustings, 2017).

Based on nationwide estimates from the 2018 Annual Homeless Assessment Report to Congress, the amount of unsheltered homeless individuals increased by $12.2 \%$ from 2015 to 2018. During this same timeframe, the amount of sheltered homeless individuals decreased by $9.2 \%$. As unsheltered homeless individuals may be at greater risk of victimization, these statistics are cause for concern. According to the 2018 Annual Homeless Assessment Report to Congress, Oregon has the second highest rate of unsheltered homeless individuals in the United States (61.7\%), second only to California (68.9\%; Henry et al., 2018). In Portland alone, a recent point-in-time count has estimated that 2,037 individuals sleep unsheltered, an increase of more than 20 percent from the city's previous point-in-time assessment in 2017 (A Home for Everyone, 2019). Given these findings, it is both important and timely to further explore risks of victimization within the context of individuals experiencing homelessness.

The purpose of this study is to build on past research through examining spatial patters of crime in proximity to reported homeless camps in Portland, Oregon by asking the following research questions:

RQ 1) Is the risk of victimization higher in proximity to reported camps, as compared to other areas within Portland, Oregon?

RQ 1a) Is the risk of victimization higher for some crime categories in these areas, than it is for others? 
RQ 2) Is the risk of victimization disproportionally higher in proximity to some camps, as compared to others within Portland, Oregon?

RQ 2a) Do the areas surrounding high-risk camps display a unique crime profile, as compared to events occurring around other camps?

The following chapters of this thesis frame this current study in the context of past literature, explain the data and methodology used, summarize and discuss the results of the study, explore limitations to the research, and offer guidance for future directions. The second chapter focuses on reviewing past literature and applying empirical findings to this present study. The literature review includes an overview of spatial theories of crime which seek to explain why crimes tend to concentrate in certain areas. Also discussed in this section are the patterns of homeless camp locations which tend to fit into unique spatial patterns. To understand the spatial relationship between homeless camps and crimes, this chapter challenges myths of homelessness and criminality and explores risks of victimization among those experiencing homelessness. Finally, to examine the local context of the study, the literature review outlines current programs and methods for supporting individuals experiencing homelessness in Portland, Oregon. Based on past empirical research discussed further in chapter two, it is hypothesized that crime will be more prevalent, and subsequently, the risk of victimization will be higher, near areas where homeless camps have been reported. It is further hypothesized that some locations will be at higher risk of victimization than others.

Following the literature review, chapter three of this thesis explains the data and methodology used to address this study's research questions. To map reported homeless 
camp locations, volunteered geographic information (VGI) was utilized (Flanagin \& Metzger, 2008; Harrell, 2019).This VGI data is made up of citizen reports of homeless locations in Portland, and contains data regarding the size, state, and occupancy of the camp locations. Offense data used for this study was available from the Portland Police Bureau's open data initiative. This data includes 100-block level locations, $\mathrm{x}$ and $\mathrm{y}$ coordinates, dates, times, and offense type for each crime event. To analyze this data, several spatial analyses were conducted using ArcGIS software. The results of these analyses are reported in chapter four, which provides answers to the research questions by identifying high-risk camp locations and exploring the concentration of crime near these encampments.

Chapter five offers an in-depth evaluation of this study's findings in the context of past research studies and theoretical applications. These findings have the potential to inform policy decisions, acting as a tool to help prioritize reported camps that may be at the highest need of public services and community intervention. As such, the discussion section will offer recommendations for future research and ways in which future studies can address the limitations of this study to advance knowledge on the risk of victimization near homeless camps. The final chapter, chapter six, is the conclusion for this research. This chapter outlines research findings and implications and emphasizes future directions and implications of this study. 


\section{Chapter II. Literature Review}

As a key goal of this study is to assess the spatial relationship between the risk of crime victimization and reported homeless camps in Portland, Oregon, it is important to review and consider literature on the topics involved. This literature review examines current research on environmental criminology and the spatial context of homelessness, as well as research considering the marginalization of the homeless population. Also covered in this chapter is literature challenging the myth of homelessness and criminality and exploring the risk of victimization among those experiencing homelessness. In addition, given the unique local factors relating to homelessness within the Portland area, it is also necessary to review the local context in which this study is set. Through expanding on past research and addressing gaps therein, this literature review both sets the scene for this current study and accentuates the importance of further assessing the spatial relationship between areas near homeless encampments and risks of victimization.

\section{Spatial Theories of Crime}

In assessing reported homeless camp and crime locations, it is important to understand the impact that neighborhood and environmental factors may have on criminal activity. Several theories exploring the connections between urban form and crime have been developed in an attempt to explain crime concentration in urban areas. With the purpose of expanding knowledge on human ecology in urban areas, Park and Burgess (1925) introduced central place theory. Based on the City of Chicago, central place theory focused on explaining the relationship between geographical space and socio-economic demographics. Park and Burgess (1925) separated the city into five zones 
and explained how the transition zone, nearest to the central business district, was both affordable and undesirable as a residential environment and was therefore populated predominantly with recent migrants and individuals with lower incomes. This area was characterized by high rates of residential turnover, caused by both growth and outward pressure from the city center, and high levels of out-migration (Park \& Burgess, 1925).

Expanding on the work of Park and Burgess (1925), Shaw and McKay (1969) introduced social disorganization theory. In this work, the authors made a connection between the urban structure as defined by central place theory, and neighborhood-level crime rates. The transition zone, they found, was connected to high rates of crime. Social disorganization theory posited that this correlation was a result of the high residential turnover within this zone, among other features. In particular, these neighborhoods were unable to develop social cohesion due to rapid changes in the population. This lack of cohesion resulted in social disorganization at the neighborhood level, and therefore fostered higher crime rates within these zones (Shaw \& McKay, 1969).

Some scholars have challenged the premise behind the work of both Park and Burgess' central place theory and Shaw and McKay's social disorganization theory, questioning their applicability within other urban locations and timeframes (Haggerty, 1971; Quinn, 1940). In years following the developments of Park and Burgess' (1925) model, scholars found that other cities such as Montreal, Quebec (Dawson \& Gettys, 1935) and New Haven, Connecticut (Davie, 1937) did not align with the concentric zone patterns. In another common critique of Park and Burgess' (1925) theory, Schnore (1957) argued that, as urban patterns are constantly developing, cities undergo structural changes 
that are inconsistent with the geographical characteristics and patterns in Chicago during the time of central place theory's inception. Further, regarding Shaw and McKay's (1969) social disorganization theory, scholars have challenged the theory's reliance on a stable ecological environment (Bursik \& Webb, 1982), arguing that longitudinal studies are necessary to test for reliable findings over time and adapt for inevitable structural changes. Despite noted limitations to the original Chicago model, social disorganization theory continues to be applied and studied in criminological work today, as scholars further examine the link between social and physical neighborhood structure and crime (Kubrin, 2009; Tian, Wu, \& Yang, 2010).

While social disorganization theory considers the neighborhood-level relationship between socio-demographic and economic neighborhood features and criminality, environmental criminology theories shift the focus away from criminality, and onto the situational elements of the criminal event itself. This group of inter-related theories focuses on the place in which crime events occur and works to explain how characteristics of a certain location may promote criminal activity in that area. Understanding the groundwork and contemporary status of environmental criminology theories is essential to this research as the spatial relationship between homeless camps and crimes may be dependent on environmental factors.

Offering an explanation for criminal activity based on opportunities for crime, Cohen and Felson (1979) introduced routine activity theory. The premise of this theory is that, for a crime to occur, there must be a suitable target, a motivated offender, and a location. Theorists further argue that crimes are more likely to occur in instances where 
there is no capable guardian to prevent the offender from committing a crime, serve as a place manager, or protect the target (Cohen \& Felson, 1979). From this perspective, criminal activity is not necessarily complex and planned, but is instead inherent in offenders' everyday routine activities. As applied to offender decision making, this theoretical approach suggests that offenders commit crime after a process of selecting a suitable target lacking a capable guardian, in an area with no environmental barriers, and at a time when they do not have a guardian supervising them (Felson, 2017).

An assumption of routine activity theory is that offenders are rational in making their decisions to commit crime by doing so in an environment where they are less likely to be caught. This ideology aligns with the rational choice perspective, a decision-making process model developed by Cornish and Clarke (1975). From a rational choice perspective, criminal offenders make decisions to commit crime after rationally considering the costs and benefits of the act. In this sense, offenders may be more likely to commit crimes in areas where the rewards from committing the crime outweigh the potential costs of being caught. From a crime prevention standpoint, areas that increase offenders' perceived risks of being caught, or their potential of being unsuccessful in their criminal attempt, will be less suitable targets for criminal activity.

In addition to rational choice theory and routine activity theory, the geometry of crime was a substantial contribution to the field of environmental criminology. The geometry of crime, like routine activity theory, explains criminal offenses as opportunistic events committed when potential offenders encounter a triggering event during their routine activities (Brantingham, P. J., Brantingham, P. L. \& Andresen, 2017). 
Upon encountering a triggering event, offenders search for a target by conducting a minimal or expansive search based on their activity and awareness areas and past experiences. These factors make up individuals' backcloths, which are essentially offenders' perceptions of the environmental structures by which they travel (Brantingham, et al., 2017). This contributes to a more thorough understanding of spatial elements of crime in the sense that the backcloth of a given location may provide opportunities for crime to take place.

Crime pattern theory, developed by Brantingham and Brantingham (1995) is a meta-theory incorporating elements of rational choice theory (Cornish \& Clarke, 1975), routine activity theory (Cohen \& Felson, 1979), and geometry of crime (Brantingham et al., 2017). Crime pattern theory seeks to understand crime as an interaction between the victim, the offender, law, and importantly, space (Brantingham, P. L. \& Brantingham, P. J., 1995). By incorporating criminal offender decision making processes, crime pattern theory suggests that crimes will occur in areas where an offender's activity space overlaps with that of a victim's. To explain the concentration of crimes in certain geographic areas, Brantingham and Brantingham (1995) introduced the idea of crime attractors and crime generators. Both crime attractors and crime generators refer to areas where crime is more likely to occur. Crime attractors are locations where criminal offenders are drawn because of the reputation for crime in the area. Crime generators, on the other hand, are areas where a lot of people gather such as shopping malls or schools. These areas promote criminal activity based on the number of individuals who can become targets for offenders. 
Building upon the framework of crime pattern theory, crime event density at and in proximity to bars, schools, transit nodes, and other facilities have frequently been the topic of analysis (Barthuly, 2019; Bernasco \& Block, 2011; Groff, 2011, Kinney et al., 2008; Ratcliffe, 2011; Wuschke \& Kinney, 2018). These studies have consistently found that crime tends to be concentrated near these establishments. Bernasco and Block (2011) assessed the impact of crime attractors and generators on robbery rates at the block level in Chicago, finding that city blocks with more retail businesses, public transport stations, and illegal markets had higher rates of crime. Other studies have reached similar conclusions. In a study on proximity of violent crime near bars in Philadelphia, Pennsylvania, Ratcliffe (2012) found significantly higher concentrations of violent crime near bars, as compared to other areas in the city. In a study on a similar topic, Groff (2011) assessed crime near drinking places in Seattle, Washington with the purpose of identifying the best way to measure nearness to these establishments. In this study, higher concentrations of crime were found near drinking placings when applying both Euclidian distance and street distance buffers (Groff, 2011).

Willits, Broidy, and Denman (2015) considered the neighborhood level impacts of crime pattern theory by assessing the relationship between drug markets and schools in Albuquerque, New Mexico. By comparing drug crime rates in neighborhoods with and without schools, Willits et al. (2015) found that drug crimes were more common in neighborhoods with high schools and middle schools as compared to those without. Similarly, Ratcliffe and McCord (2007) noted that environmental measures of social disorganization considering presence of beer establishments and social demographics 
were found to be predictors of the size and location of drug markets in Philadelphia, Pennsylvania.

To assess crime near public transportation nodes, Gerell (2018) conducted a spatial analysis by applying spatial buffers to bus stops and nearby facilities including restaurants, bars, nightclubs, ATMs, and schools. By analyzing crime concentration in the overlap in spatial buffers between facilities and bus stops, Gerell (2018) found that violent crimes were more concentrated in areas near restaurants, bars, and ATMs. In a similar study, Barthuly (2019) analyzed crime in proximity to mass transit nodes in Portland, Oregon, finding that robbery concentration was almost 15 times higher within 400 feet of these nodes compared to robbery crimes in the city. Barthuly's (2019) study emphasized important differences between transit nodes, noting that a small percentage of the city's mass transit hubs accounted for a dramatically higher proportion of the city's robbery occurrences (Barthuly, 2019).

Barthuly's (2019) consideration of the important impact of a small number of crime attractors echoes work of both Kinney and colleagues (2008), and Wuschke and Kinney (2018). These studies assessed crime events across a variety of spatial scales, analyzing the specific land use category in which crime events occurred. Findings from these studies indicated that commercial and civic, institutional, and recreational land uses were associated with high concentrations of crime at the city-wide level. However, within these categories, there existed further variation - while some commercial land use types, such as shopping centers, exhibited high concentrations of crime, other types of commercial land use were the site of very few crime events. Further, not all shopping 
centers in these studies were found to be over-represented. These findings emphasize the importance of local-level analysis and analysis across a variety of spatial scales (Kinney et al., 2008; Wuschke \& Kinney, 2018).

Environmental criminology theories and studies all support the overarching principle that crime, like the bulk social phenomenon, is not random. Instead, crime can be understood as a product of environmental characteristics which can guide crime patterns. As applied to this current research, reported homeless camp locations may be influenced by environmental characteristics in similar ways. The overlap in characteristics which may promote both criminal activity and homeless camp locations is imperative to this research because it may explain how camps and crimes are located in similar areas. This connection could lead to increased risks of victimization among vulnerable populations.

\section{Homelessness and Victimization}

Several factors have been identified by researchers as indicators of high victimization rates among members of the homeless community. Among these factors are the impact of adverse childhood experiences and mental illness. Edalati et al. (2017) considered these factors through evaluating 1,888 homeless individuals from five different Canadian cities, all of whom reported being mentally ill at the time of participation. Findings from this study suggested that mentally ill homeless individuals who reported an adverse childhood experience involving abuse or neglect were more likely to have been involved in the criminal justice system within six months prior to their participation in the study. These individuals were also more likely to have a history 
of victimization within the same six-month period. Additional research has found similar results identifying mental health concerns, childhood trauma, alcohol abuse and illegal drug use as indicators of victimization (Desai, Arias, Thompson \& Basile, 2002; Edalati et al., 2017; Maniglio, 2009; Teplin et al., 2005). As these indicators are prevalent among members of the homeless community (Susser \& Valencia, 1997; Tessler, Rosenheck \& Gamache, 2011; Weitzman, Knickman \& Shinn, 1992), they are necessary to understand in the scope of this thesis. Importantly, this current study is unable to indicate any causal relationship between homeless status and victimization. Instead, this research will assess the spatial relationship between reported homeless camps and crime concentration by considering the risks of victimization near these encampments.

In addition to mental illness and childhood abuse and neglect, researchers have found sexual and physical victimization to be prevalent among samples of marginally housed and homeless individuals. Kushel et al. (2003) surveyed 2,577 homeless adults from seven San Francisco shelters to assess physical and sexual victimization rates among other factors. The participants identifying as transgender in their sample reported the highest victimization rates $(38.1 \%)$ compared to $32.3 \%$ of women, and $27.1 \%$ of men respondents. While this current research will not be able to directly assess victimization rates, understanding the spatial relationship between crime patterns and reported homeless encampments will provide further insight into potential concerns with the homeless-victimization cycle to guide future policy-making, service delivery, and policing strategies. 
The victimization of homeless individuals has been found to have further adverse effects. North, Smith, and Spitznagel (1994) argued that victimization within homeless communities tends to be associated with aggression. Through conducting research on a sample of 900 homeless individuals in Saint Louis, Missouri, the authors found high rates of physically aggressive behaviors that appeared to be exacerbated by substance abuse and mental illness symptoms. They theorized that addressing either housing instability or mental illness would alleviate concerns of aggression and future victimization by reducing risk and increasing societal support and feelings of security. If the relationship between aggressive behavior and victimization is cyclical, timely connections with support services may prevent future harm.

Further exploring the relationship between victimization and homelessness, Lee and Schreck (2005) assessed the impact of various internal and external factors on the likelihood of victimization among a sample of 2,401 individuals receiving homeless services including emergency shelter, meals, and health care. Preliminary results from this study found that $54.0 \%$ of respondents reported some form of victimization while living on the streets. Of this $54.0 \%, 49.5 \%$ reported a theft of property, $21.3 \%$ reported at least one physical assault, and $11.4 \%$ of female respondents reported a rape. Additional studies have reached similar results across various demographics and locations. Among a sample of 1,103 Canadian youth experiencing homelessness, $68.7 \%$ reported being a victim of crime in the past year compared to an average of only $19.0 \%$ of the Canadian population in any given year (Gaetz, O’Grady, Kidd \& Schwan, 2016). Concerning 
violent victimization, Gaetz et al. (2016) found that $59.6 \%$ of these youth participants reported being victim to a violent crime compared to $7.6 \%$ of the general population.

\section{The Myth of Homelessness and Criminality}

Although public attitudes and perceptions of the homeless community have improved in the past few years (Tsai et al., 2017), stigmatization and fear of homelessness still exist (Turner, Funge, \& Gabbard, 2018). Both stigmatization and fear of homelessness have been found to be enhanced by the media in different ways. Borchard (2005) conducted a content analysis of newspaper articles and other documentation featuring homelessness, identifying a common theme that homeless men should be feared. Even in instances where homeless individuals were victims of crimes, Donley and Gualtieri (2017) found that the victims' homeless status tended to be a consistently prominent aspect of analyzed news reports. Donley and Gualtieri (2017) further found that victims experiencing homelessness were often framed in a positive light with acknowledgement that the positive factors were contrary to homeless stereotypes. These media portrayals exacerbate the assumptions that individuals experiencing homelessness are violent or dangerous (Department of Commerce, 2016). Several empirical articles have been published in the past few decades providing evidence dispelling this myth.

With the purpose of providing insight into the relationship between criminality and homelessness, Snow, Baker, and Anderson (1989) conducted a study examining the criminal activity of 767 homeless individuals who were involved with the Salvation Army. Based on results from this study, less than one third of the respondents had contact 
with the local police department and most of these contacts were regarding non-violent offenses. More recent studies have found similar trends with lower rates of violent crimes compared to nonviolent crimes among the homeless community (Delisi, 2000; Fischer et al., 2008). Among a sample of 100 homeless jail inmates and 100 domiciled jail inmates, Delisi (2000) found no significant difference between the likelihood of being arrested for a violent offense. Regarding nuisance offenses, however, homeless inmates were 1.7 times more likely to be arrested than domiciled inmates.

Fischer et al. (2008) took a closer look at a sample of 218 mentally ill homeless individuals to compare differences in criminality among those who were sheltered and unsheltered. This study further addressed the myth of homelessness and increased criminality through explaining how members of the homeless population were perceived to commit more crime based on higher rates of non-violent offenses. Results from this study found that sheltered homeless individuals were more likely to commit a violent crime than unsheltered homeless individuals, which further contradicts public fear of individuals living on the streets. In response to the positive relationship between homelessness duration and non-violent crime, Fischer et al. (2008) argued that nonviolent offenses by homeless offenders, though technically criminal by definition, should be framed as a survival tactic instead of as criminal behavior.

Further refuting the myth of violent criminality and homelessness, Fitzpatrick and Myrstol (2011) conducted interview research on a sample of 47,592 arrestees from 30 jails. To assess differences in arrest types by homeless status, they compared the sample of arrestees who reported being homeless for at least 15 out of the 30 days leading up to 
their most recent arrest to participants who did not. Based on results from this analysis, homeless individuals were found to be less violent, and jails held a disproportionate number of homeless individuals who were arrested for non-violent offenses. In this sense, Fitzpatrick and Myrstol (2011) argued that these jails were focusing on enforcing the social offensiveness of homelessness instead of enforcing violence by dangerous criminals. Understanding myths and empirical evidence surrounding homelessness and criminality is important to this present study, as public perceptions may influence citizen reporting, and public response to concerns faced by those experiencing homelessness may further guide policy decisions and resource distribution.

\section{Spatial Context of Homelessness}

Before considering the local relationship between crime and homeless camp locations, it is important to understand how individuals experiencing homelessness may choose their living spaces. In order to avoid public complaints and law enforcement involvement, individuals seeking shelter and safety must choose camp spaces carefully. This process can be difficult due to several societal constraints. Snow and Mulcahy (2001) studied this process in order to gain an understanding of what factors motivate and restrict spatial patterns and decisions of homeless individuals. Throughout their research, they identified several prominent restraints faced by the homeless community. Legal factors prevent homeless individuals' abilities to legally occupy public space, and social constraints in the form of harassment or ridicule by the public may lead individuals further away from public resources. As homeless individuals tend to rely on public resources for safety and survival, this further limits selection options. 
Homeless camp locations are also inevitably driven by policing efforts and strategies. Snow and Mulcahy (2001) discussed control tactics used to address concerns surrounding homelessness based on their research observations. These tactics have been labeled by other scholars as the criminalization of the homeless. The criminalization of homelessness refers to methods used by law enforcement officers to enforce public ordinances preventing homelessness, often in response to public outcry (Amster, 2008). Methods used by law enforcement may involve arresting homeless individuals, ordering individuals to leave their current locations, or cutting off necessary resources to force movement (Snow \& Mulcahy, 2001). These methods further contribute to the transitional nature of homeless camps, and essentially do very little to address the problems inherent in homelessness. By assessing whether crimes, and therefore the associated risk of victimization, are prevalent near homeless locations, this research can further guide strategies to support the safety and security of individuals residing at or near reported homeless camps.

Results and findings from this study apply to Portland, Oregon. As such, the dynamics of Portland's homeless community should be considered. Though this specific research is limited, the City of Portland (2019b) has created a database of local reports of temporary encampments in an effort to both track and serve the city's unsheltered homeless population. This data is primarily used for the provision of outreach and support, as well as for campsite clean-up. Harrell (2019) utilized this Portland dataset to assess spatial patterns of homeless camps in Portland as well as the spatial relationship between these camps and support services. Findings from Harrell's (2019) research 
suggested that homeless camps tend to be concentrated near main streets, support services, transit nodes, and commercial areas. This current research will build on the groundwork conducted by Harrell (2019) by exploring the risks of victimization as measured through patterns of crime within close proximity to reported homeless encampments in Portland.

\section{Homelessness in Portland: Considering the Local Context}

A recent publication from the City of Portland outlines their current strategies for addressing homelessness (City of Portland, 2019c). This report accentuates that, although overall counts of individuals experiencing homelessness in Portland have been decreasing for the past two years, reports of unsheltered homeless individuals in Portland have been on the rise. Also increasing in Portland are the number of individuals experiencing chronic homelessness. This refers to individuals who have been homeless for at least a year, many of whom are known to experience a mental health condition, chronic illness, or an addiction disorder. A general look at the overall statistics may suggest that housing programs are making a significant positive impact on Portland's community. Considering the unsheltered rates, however, further intervention is needed.

One significant effort made by the City of Portland was the development of their Homelessness and Urban Camping Impact Reduction Program (HUCIRP). The primary goals of the HUCIRP are to increase communication and awareness of their current programs, increase access to hygiene and sanitation services, and develop more lawful places to sleep. This program is also responsible for collecting and responding to reported data regarding homeless camps in Portland. Upon receiving citizen reports identifying 
homeless camp locations, the HUCIRP conducts a risk assessment to assist in identifying the most vulnerable camps (A Home for Everyone, 2019; The City of Portland, 2019a). Weekly, focusing on camps found to have higher risks, the HUCIRP initiates a "cleanup" process (The City of Portland, 2019a, para. 6). The initial step in this process is to post a notice to all selected high-risk camps, at least 48 hours in advance, advising occupants that property from the site will be removed. Next, the HUCIRP sends notifications to social service agencies, community advocates and other resources with the purpose of connecting camp occupants to necessary services. A Navigation Team was recently created to assist with this process (The City of Portland, 2019b). Although the HUCIRP emphasizes their prioritization of vulnerable homeless campsites (A Home for Everyone, 2019) and the Navigation Team clearly states their focus on "high-impact" sites with health and safety concerns (The City of Portland, 2019b, p. 1), the specific procedures for prioritizing reported camps are unclear.

The City of Portland was selected as the location of this study primarily based on the available reported homeless camp data and the opportunity to contribute to the current risk assessment used by the city to identify high-risk sites. Although Oregon has been identified as one of the states with the highest proportion of unsheltered individuals experiencing homelessness, homeless trends in Portland are comparable to other major urban cities (Harrell, 2019; Henry et al., 2018). Considering homeless rates among arrestees in several states, Portland has been found to be similar to New York, Atlanta, and Denver (Speiglman \& Green, 1999). Further, the City of Portland has been compared to other cities, such as Nashville and Tuscon, regarding crime trends (Cahill, 2003). With 
these similarities in mind, although the findings from this study are only generalizable to the Portland area, results of this thesis emphasize the need for, and benefit of, conducting similar research in other urban cities across the United States.

\section{Research Contribution}

This proposed study can contribute to the prioritization of homeless camps in Portland by providing overall risk of victimization, as measured by the density of crime incidents, near reported homeless campsites. This information can be incorporated into a risk assessment toolkit by identifying individual sites located in areas with the highest crime concentrations. The prevalence of crime in proximity to homeless camps may enhance the need for services and intervention in these locations. In this sense, this research may further inform decision-making processes made by Portland organizations working to prioritize homeless encampments based on need. The City of Portland (2019a; 2019c) emphasizes that they strive to make a difference in the lives of individuals experiencing homelessness. Through providing an additional measure of potential need for resources, this present study can further guide Portland organizations toward serving the homeless community more effectively. 


\section{Chapter III. Data and Methodology}

This chapter offers an in depth look at the methodology and analytical strategies applied to address this study's research questions. Starting with a synopsis of the data sources used, basic univariate statistics are summarized in this section to provide a general overview of the datasets. Next, methodological approaches for this study are discussed. These procedures were formed in conjunction with those of past studies including Barthuly (2019), Groff (2011), and McCord and Ratcliff (2007). This methodology section works to explain how these past studies contributed to decisions made for this research regarding distance used to measure proximity to homeless camps and calculations applied to determine differences in crime concentration within these areas.

\section{Data Sources}

Data used for this study were drawn from two publicly available data sources. Crime data was accessed through the Portland Police Bureau crime database which provides information on reported crime offenses in the Portland area. This data is typically updated each month and includes geographic information for reported crimes as well as information regarding the type of crime event. Campsite data was provided through a public records request submitted to the City of Portland. This data is classified as volunteered geographic information (VGI) as it consists of reports entered by citizens (Flanagin \& Metzger, 2008; Harrell, 2019). This dataset includes geographical coordinates for each camp location as well as details regarding the camp occupancy and additional reported concerns. 


\section{Homeless Camps}

For research purposes, individuals experiencing homelessness are typically categorized based on their sheltered or unsheltered status (Henry et al., 2018; Nyamathi, Leake, \& Gelberg, 2000). Generally, individuals are classified as members of the sheltered homeless population if they do not have their own permanent living quarters, but sleep in shelters or other established structures. In contrast, individuals are considered to be experiencing unsheltered homelessness when they live and sleep in areas not intended to be used as an inhabitance, which includes individuals residing in tents, cars, or makeshift living quarters (Henry et al., 2018).

This current study builds upon a unique dataset by assessing homeless camp locations, rather than considering individuals experiencing homelessness as the unit of analysis. Data regarding homeless camp locations were drawn from the City of Portland's One Point of Contact Campsite Reports which is part of the local Homelessness and Urban Camping Impact Reduction Program (The City of Portland, 2019a). This database consists of homeless camp locations around the city voluntarily reported by community members via phone or internet. The City of Portland website, updated regularly, offers a map of reported data points, which provides the report date, report time, and spatial attributes of all reports occurring in the past week. The goal of this data collection is to guide the city's initiative to aid the homeless community through offering connections to resources and shelter and taking steps necessary to clean the camp site locations.

The conceptualization of homeless camps is not one that has been used throughout many empirical studies (see, for example, Harrell, 2019). The definition of 
homeless camps for the purpose of this research is based on the City of Portland's data collection methods. To report a campsite, the City of Portland (2019a) specifies that one of the following criteria should be met:

- Repeated instances of overly aggressive behavior from campers (Direct verbal threats or physical actions clearly meant to intimidate such as chasing, looming, or raising a fist. Call 91-1 to get assistance in the moment, and fill this form out later.)

- Public intoxication and/or conspicuous drug use (Again, if it is an emergency, please call 9-1-1.)

- Campsite obstructs public right-of-way (e.g., sidewalks, trails)

- Misuse of public spaces (e.g., using it as a restroom)

- Structures (e.g., lean-tos, mass shelters)

- Excessive trash and/or biohazards (e.g., discarded syringes)

- Damage to the environment (e.g., cutting down trees or limbs, digging a trench into a hillside, etc.)

(The City of Portland, 2019a, para. 2)

There are currently two online options available to report a campsite to the City of Portland. One option is to utilize the city's online reporting system, PDX Reporter v0.9.1, which is a website application used to report a variety of concerns including potholes on roadways, graffiti, and parking concerns in the Portland area. To report a campsite using this reporting method, individuals are first prompted to identify the location of the camp. The location is reported by placing a pin on an interactive map of Portland. Location services are also used to assist reporting parties who are near the camps during the time of their report. After identifying the camp location on the map, users are provided the opportunity to upload photos of the location and additional comments that may help the Navigation Team identify the site. To provide additional details of reported camp locations, citizens can utilize an online form available on the City of Portland's website (The City of Portland, 2019a). In this case, individuals input an address near the camp 
location which they can then verify on a map by dragging a pin to the specific site. This form also contains a series of questions about the camp area including the presence of children, dogs, or vehicles, apparent need for medical attention, and environmental concerns. Citizens utilizing this reporting method are also able to provide comments and photos of the area.

There are certain considerations to keep in mind when utilizing voluntarily reported data. First, as these camps are documented only when reported by the public, this dataset acts as a proxy for the spatial distribution of Portland's population experiencing unsheltered homelessness. As with any report-based dataset, this may not represent a complete picture of the spatial patterning of homeless camps within Portland. Second, as the data for this current study is voluntarily reported, the interpretation of homeless camps and the above guidelines are based on the individual reporter and therefore may not consistently meet the same criteria. Third, the motivations for reporting homeless camps are unknown. Homeless camps may be more likely to be reported in areas with high public usage, which could potentially skew results if crimes are occurring near camps which are not as visible to the public. Also, homeless camps may be more likely to be reported in areas where crime is more likely to be reported, which could impact the interpretation of this study's results. With these potential limitations in mind, this homeless camp data is still extremely valuable as it draws from several citizen sources to provide a spatial understanding of the transient nature of homeless encampments. 


\section{Reported Homeless Camps in Portland, OR}

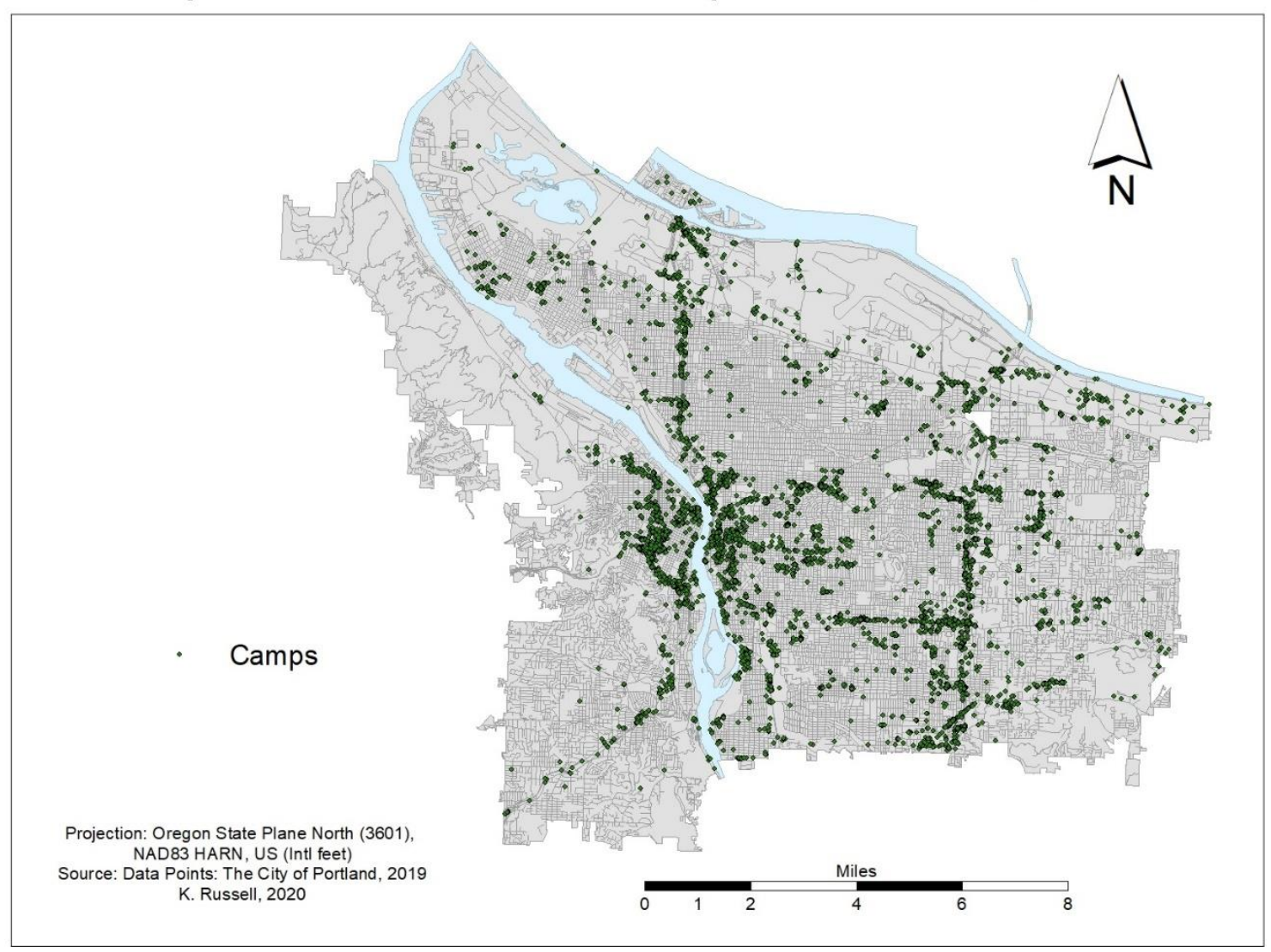

Figure 1. Reported homeless camp locations in Portland, OR from October 2019 through December 2019 $(n=9,828)$

The homeless camp dataset utilized for this study was obtained from the City of Portland through a public records request. This dataset contained information on 9,853 campsite locations reported from October through December 2019. This limited time frame was selected for this study to alleviate potential concerns with the same campsites being reported multiple times. Even so, there is a possibility that, over time, campsites are reported repeatedly or imprecisely reported in nearby locations. The HUCIRP attempts to address concerns with inaccurate reports by sending the Navigation Team to visit each reported camp location. Included in the final VGI dataset used for this study were the 
date and time of the campsite report, an indication about whether the camp has a vehicle present, and the spatial coordinates associated with these events. This dataset also contained information for some camps regarding how long the campsite has been present, the number of individuals on site, environmental and medical concerns, and the presence of children. After excluding 25 campsite locations that were outside of the Portland city limits, 9,828 reported campsite locations were used for this study. Figure 1 shows the spatial distribution of these camps on a map of Portland.

\section{Crime}

Crime data used for this study were accessed through the Portland Police Bureau's online crime statistics. This data is publicly accessible through Portland's open data policy. The crime data incorporated into this study contained incident-level crime offense data, with records including the date and time, address, neighborhood, offense type, and spatial coordinates of incidents reported to the Portland Police. Locations in this dataset were generalized at the block level, and both block and coordinate-based locations are removed for all incidents involving sensitive information, such as with violent crime events, in order to protect the identity of individuals involved (Portland Police Bureau, 2020a).

In order to capture an assessment of the spatial distribution of reported crime events in proximity to homeless camps, police data were used for all events reported in $2019(\mathrm{n}=58,861)$. A total of 6,013 crime events did not contain geographical information as they were determined by the Portland Police to be sensitive in nature. Of the available spatial datapoints, 271 events were excluded for this analysis because they 
occurred outside of the Portland city limits. Out of the total count of crime events occurring in Portland in 2019 utilized for this analysis $(n=52,577), 86.7 \%$ were classified within the data as property crimes $(n=45,587), 8.8 \%$ were crimes against a person $(n=$ $4,647)$, and $4.5 \%$ were crimes against society $(n=2,343)$. Figure 2 provides a visual representation of the distribution of these crime events in Portland.

\section{Crime in Portland, OR - 2019}

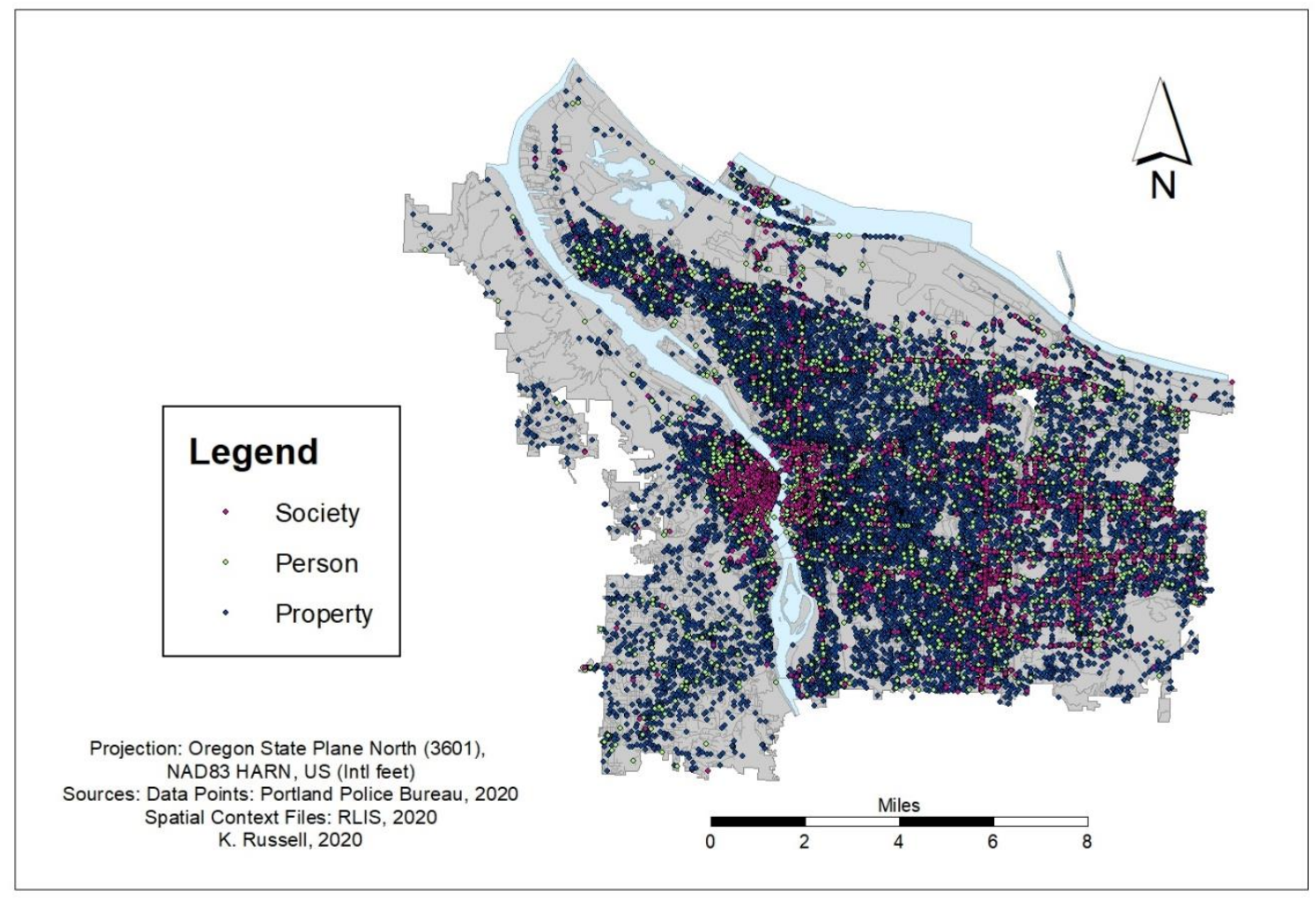

Figure 2. Spatial representation of crimes reported in Portland, OR in 2019 by crime category $(n=52,577)$

To understand the unique spatial distributions of different types of crime, this research sorted crime data into three different categories. The influence of person crime was measured based on reported crimes against persons including simple assault, aggravated assault, and intimidation. Property crimes were measured based on reports of 
vandalism and larceny offenses. Drug and narcotic violations were included in the third and final category, classified by the Portland Police as society crimes. Society crimes also cover weapon law violations, prostitution and pornography offenses, and animal cruelty. Table 1 displays the final distribution of offense counts utilized for this study, by category.

Table 1. Crime Offense Incidents by Category: Portland, OR - 2019 (Portland Police Bureau, 2020b)

\begin{tabular}{lrr}
\hline Crime Category & $\boldsymbol{f}$ & $\boldsymbol{\%}$ \\
\hline Person & 4,647 & $8.8 \%$ \\
Society & 2,343 & $4.5 \%$ \\
Property & 45,587 & $86.7 \%$ \\
Total & $\mathbf{5 2 , 5 7 7}$ & $\mathbf{1 0 0 \%}$ \\
\hline
\end{tabular}

Several spatial layers were also necessary for completing this analysis and providing context for this study. These spatial files were acquired from Oregon Metro's Regional Land Information System (RLIS) which is an online database of spatial data layers available for public use. RLIS map layers used for this study include city limits showing the Portland boundary, neighborhood organizations, major rivers, and Portland streets (RLIS, 2020). The Portland boundary file available on RLIS was drawn from Boundary Commission and Oregon Secretary of State filed annexations. The Portland streets data layer is used for emergency service dispatch and is therefore updated regularly. Neighborhoods referred to throughout this study are in accordance with the Portland metropolitan region neighborhood organization boundaries based on the corresponding RLIS datafile. This neighborhood map layer contained boundaries for 155 Portland neighborhoods. 


\section{Methodology}

This study utilized ArcGIS's ArcMap 10.7.1 to conduct spatial analyses on homeless camp and crime data in Portland. To conduct these analyses, both camp and crime occurrence datasets were cleaned, formatted, and imported into ArcMap, and displayed using their included $\mathrm{x}$ and $\mathrm{y}$ coordinates. In order to address RQ 1 , which considers whether risk of victimization concentrates disproportionally in proximity to Portland's reported camps, a series of spatial buffers were applied to the homeless camp data. Following the methodology applied by Groff (2011), buffer distances were selected based on the calculated average distance of one city block within Portland, Oregon (349 feet). The first phase of this study incorporated dissolved buffers to ensure results were not skewed by crimes in close proximity to multiple reported homeless camp locations (see Figure 3). Buffers were applied using Euclidian distances, contrary to best practices to rely on network-based distances, as noted by Groff (2011). However, given the nature of the camp data, which are not tied to the road network but are rather identified based on user-described inputs, buffer distances based on the road network would not allow for adequate measurement of concentration in proximity to these features.

To assess differences in crime concentration as distance from campsites increases, buffer distances were increased by 349-foot intervals, extending away from the initial camp location for three city blocks (1,047 feet). To apply these buffer intervals, a multiple ring buffer analysis was used. While phase one of this study incorporated dissolved Euclidean buffers surrounding reported campsites, the multiple ring buffer analysis allowed for an understanding of how crime density changes as distance away 
from homeless camps increases. Figure 3 shows dissolved buffers surrounding six different homeless camps at 349-foot intervals. After applying buffers to the camp layer, a spatial join was conducted between the crime points and camp buffers. This join allowed for an assessment of the count of crime events occurring within each buffer area. Taking this a step further, these results were differentiated by crime type.

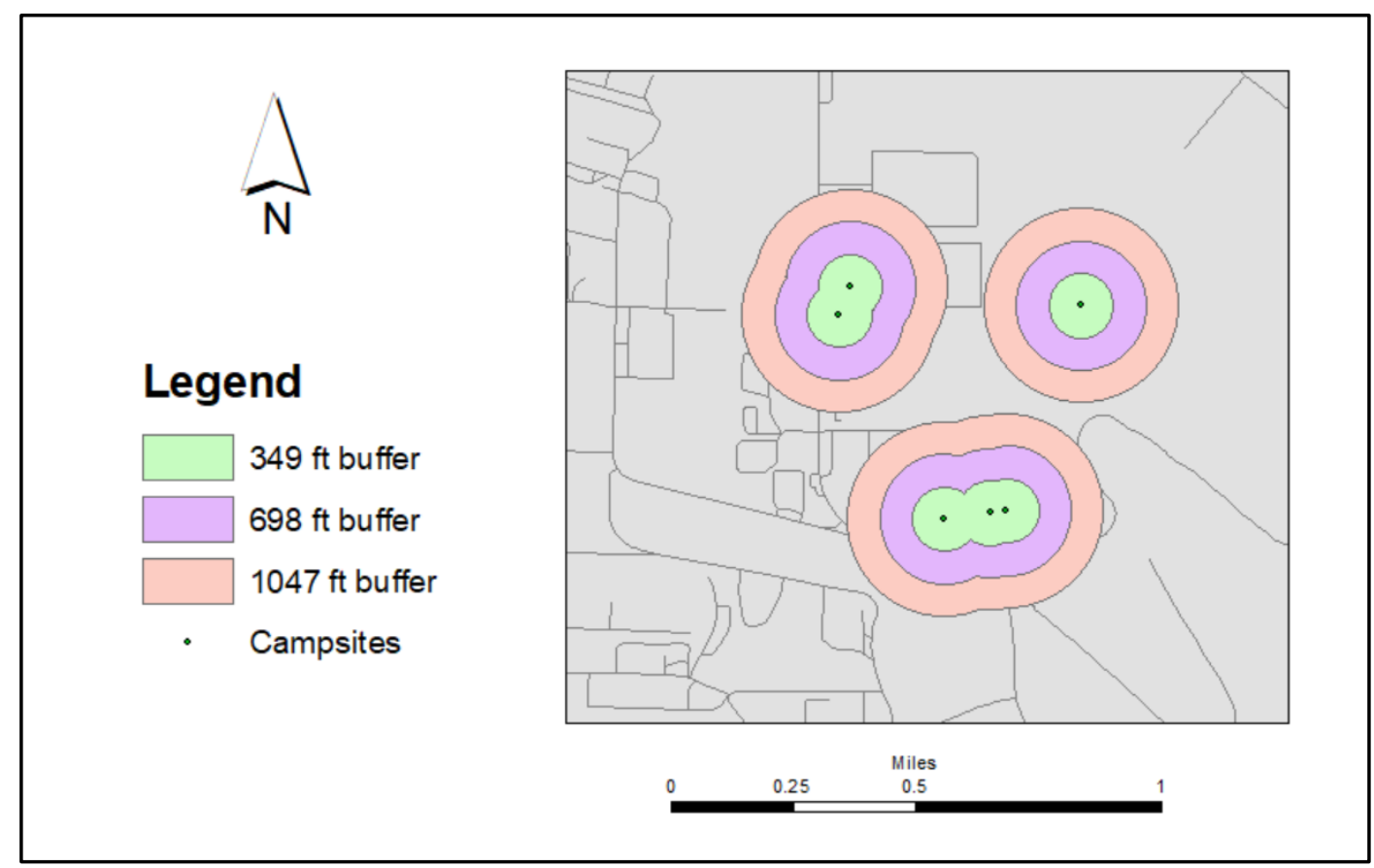

Figure 3. Multiple ring buffers in 349-foot intervals around reported homeless camp locations

Location quotients were used to measure the concentration of different types of crime within the homeless camp buffers. Location quotients measure crime density (crimes per area) within buffers, as compared to the crime density (crimes per area) in the study area as a whole. The following formula is used to calculate location quotients (McCord \& Ratcliffe, 2007):

$$
L Q=\frac{c_{i} / a_{i}}{c_{R} / a_{R}}
$$


Where:

$c_{i}=$ crime count within homeless camp buffers

$a_{i}=$ total area of homeless camp buffers

$c_{R}=$ total crime count in Portland

$a_{R}=$ total area of Portland

Location quotients allow for a simple but powerful comparison of relative crime concentration within areas and have been frequently used within spatial analyses to identify features and areas with an overrepresentation of crime (Barthuly, 2019; Groff, 2011; McCord \& Ratcliffe, 2007). Areas with a location quotient of 1.0 exhibit crime concentrations equal to that of the city as a whole. Location quotient values of greater than 1.0 indicate a higher-than-average concentration, while values less than 1.0 indicate lower than expected concentrations. This metric has the benefit of being relatively easy to interpret - a location quotient value of 3.0, for example, indicates that the area has three times the rate of crime per area than the city as a whole.

Despite the prevalent use of location quotients in academic studies, there is debate regarding what level of concentration may be indicative of a meaningful hotspot of crime. This study relied on the stringent guidance from Groff's (2011) research, which considers a location quotient of 2.0 or more to indicate a meaningful spatial concentration of crime events within the study site. In this study, a location quotient of two would indicate that crime within the camp buffers is twice as concentrated as crime in the city and may be indicative of a higher risk of victimization within these areas. The results from this 
analysis address this study's RQ 1 by directly measuring the concentration of all crime, and different crime subtypes (RQ 1a), in proximity to reported homeless camp locations.

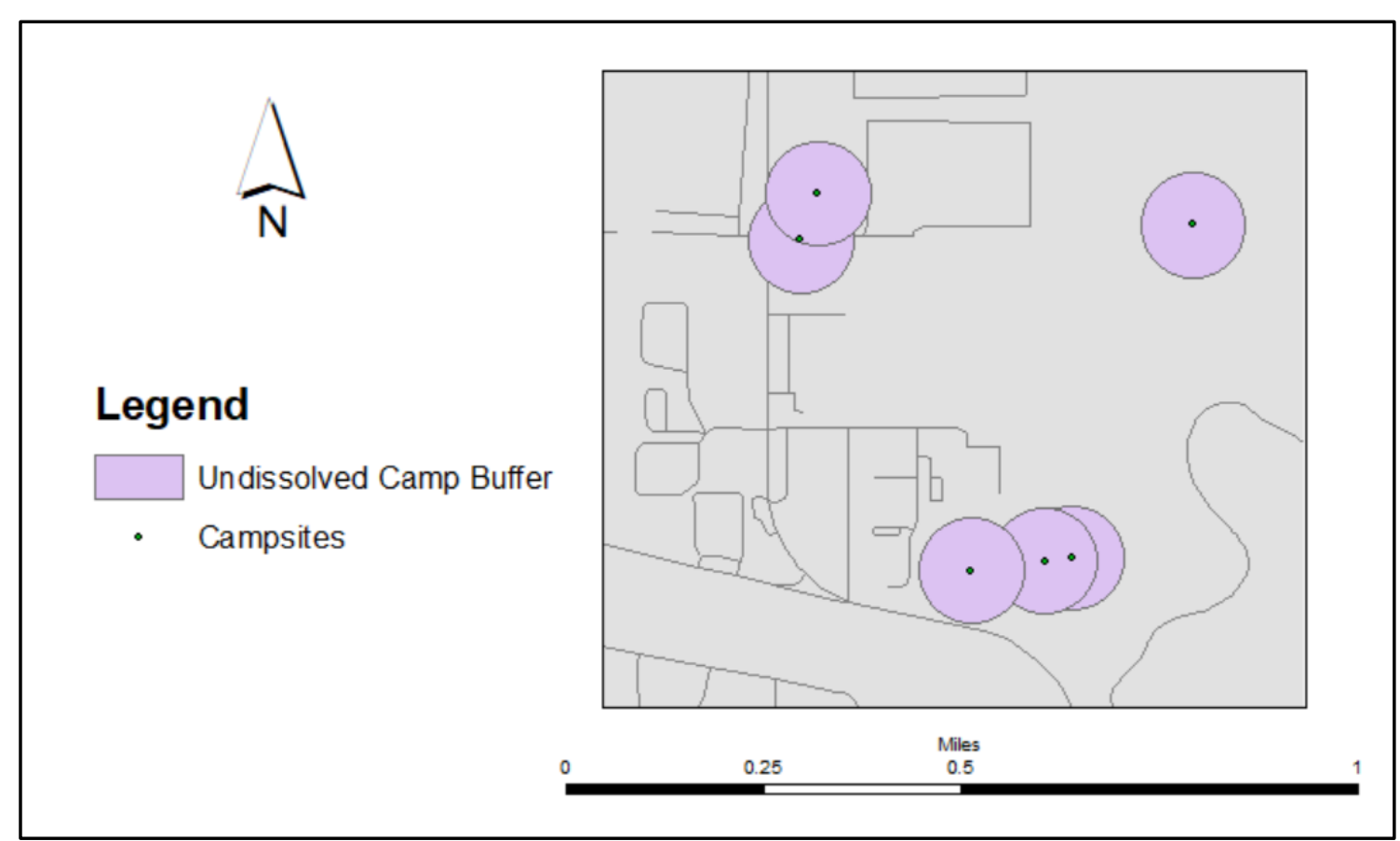

Figure 4. 349-foot undissolved buffers surrounding reported camp locations

Recognizing that crime concentration may vary between reported camp locations, the second research question of this analysis addresses crime concentration near each individual reported camp location. In this case, individual spatial buffers were created around each reported campsite at a distance of 349 feet. Although these undissolved spatial buffers would inflate overall event counts near homeless camp locations by double-counting events occurring within 349 feet of more than one reported encampment, they are necessary for this phase of the analysis in order to identify individual camps with the highest risk of victimization within this distance. Figure 4 provides a visual representation of these undissolved homeless camps to allow for an assessment of crime counts within these individual buffers. Location quotients were used to measure crime 
density in these locations, with the goal of identifying whether some encampments may be at higher risk of victimization than others. This analysis addresses RQ 2 by measuring crime events occurring in close proximity to individual camp locations to determine which reported homeless camps may face a higher risk of victimization. Identifying homeless camps at highest risk allows for the ability to prioritize service delivery and community intervention in these locations.

One of the priorities of the City of Portland's Homelessness and Urban Camping Impact Reduction Program is to protect vulnerable populations through preventing homelessness and increasing housing opportunities (The City of Portland, 2019c). To address this goal, the high number of homeless camps in Portland suggests the need for prioritization of the most vulnerable camps. According to their 2019 report, the City of Portland currently considers many factors contributing to the prioritization of homeless camps including racial disparities, age, and health concerns (A Home for Everyone, 2019; The City of Portland, 2019c). Although acknowledging housing challenges faced by individuals transitioning out of the criminal justice system, the impact of crime on the homeless community is not further discussed or considered in their report. This current study will address this gap by providing an additional measure of vulnerability through identifying camp locations that face higher risks of crime victimization, contributing to the overall understanding of the spatial relationship between reported homeless camp locations and crime. 


\section{Chapter IV. Results}

Addressing this study's research questions, this chapter provides an overview of the analytical results of this study. First, results are reported for RQ 1 based on location quotients comparing the concentration of crime within one-block of homeless camps to the concentration of crime in the city overall. To further understand the spatial distribution of crime near reported camps, results from a multiple ring buffer analysis were also reported. In addressing RQ 1a, these analytical strategies were applied to each crime category. These results provide a more in-depth understanding of how different crimes concentrate near reported homeless camps in consideration of different victimization risks. As RQ 2 questioned whether some reported camp locations had higher concentrations of crime within their buffers compared to other camps, individual undissolved buffers were applied to each camp. Results from this analysis were used to identify reported camps with the highest concentrations of crime, and therefore the highest risk of victimization, within a block radius. These results were further applied by individual crime type to address RQ 2a.

\section{Research Question 1}

In order to address this study's first research question, a location quotient was calculated to compare the density of crimes within 349 feet of reported homeless camps in comparison to the density of crime in Portland as a whole. The total area of all dissolved 349-foot buffers around the 9,828 reported homeless camp locations was $566,113,710$ square feet, which makes up $14.0 \%$ of the area of Portland $(4,044,437,539$ square feet). Results from a spatial join indicated that 21,349 crime events occurred 
within a homeless camp buffer. This means that $40.6 \%$ of total crime events occurred within 349 feet of at least one reported homeless camp location. The calculated location quotient based on these statistics was 2.9, which indicates that crime is almost three times more concentrated near homeless camp buffers as compared to the city overall (see Table 2).

\section{Multiple buffers}

To understand how crime concentration varies as distance from campsites increases, multiple ring buffers were incorporated into this analysis. These results showed a general decrease in crime concentration as distance from campsites increased. At distances greater than 349 feet but less than or equal to 698 feet from reported campsites, crime remained concentrated at rates 1.7 times higher than across the city as a whole. While over-represented, this concentration does not meet the threshold of 2.0 used within this study to indicate a meaningful concentration. Likewise, when moving outward one further buffer distance, the associated location quotient dropped to 0.9 , indicating that concentrations at this distance are lower than in the city as a whole. Table 2, below, highlights these overall concentrations. As crime events were concentrated within a oneblock radius from campsites, subsequent analyses are centered at this spatial scale.

Table 2. Crime counts, area, and location quotient values as distance from camps increase

\begin{tabular}{cccc}
\hline Buffer Distance & Count of Crime & Area $(\mathbf{s q} \mathbf{f t})$ & LQ \\
\hline $349 \mathrm{ft}$ & 21,349 & $566,113,710$ & $\mathbf{2 . 9}$ \\
$698 \mathrm{ft}$ & 14,636 & $671,755,350$ & $\mathbf{1 . 7}$ \\
$1047 \mathrm{ft}$ & 7,048 & $575,708,880$ & $\mathbf{0 . 9}$ \\
City & $\mathbf{5 2 , 5 7 7}$ & $\mathbf{4 , 0 4 4 , 4 3 7 , 5 3 9}$ & $\mathbf{1}$ \\
\hline
\end{tabular}




\section{Research Question $1 a$}

To assess the independent relationships between homeless camp locations and crime category, location quotients were calculated for person, society, and property crimes. Out of 4,647 crimes against people reported in 2019, 50.2\% occurred within one block of a reported homeless camp. The location quotient for these crimes was 3.6, indicating that the density of person crime within homeless camp buffers was 3.6 times more concentrated than in Portland as a whole. A total of 1,395 crimes against society occurred within homeless camp buffers which account for $59.5 \%$ of this category. Based on the location quotient, crimes against society were found to be 4.2 times more concentrated near homeless camp locations as compared to the greater Portland area $(\mathrm{LQ}=4.2)$. Property crimes were found to be 2.8 times more concentrated within homeless camp buffers with $38.7 \%$ of property crime events reported in this area (LQ= 2.8). These results are displayed in Table 3.

Table 3. Crime counts and location quotient values, separated by crime category

\begin{tabular}{lccc}
\hline Crime Category & $\boldsymbol{f}$ & $\boldsymbol{\%}$ & LQ \\
\hline Person & 2,334 & $50.2 \%$ & 3.6 \\
Society & 1,395 & $59.5 \%$ & 4.2 \\
Property & 4,647 & $38.7 \%$ & 2.8 \\
Total & $\mathbf{2 1 , 3 4 9}$ & $\mathbf{4 0 . 6 \%}$ & $\mathbf{2 . 9}$ \\
\hline
\end{tabular}

\section{Research Question 2}

To address this study's second research question, spatial analyses were applied to the data to assess differences at the individual camp level. A spatial join between undissolved buffers and crime points was used to identify camps with the higher number 
of nearby crimes. Location quotients from the top 10 highest risk camps were calculated in relation to crime concentration in Portland, and crime concentration within all homeless camp buffers. Table 4 lists these 10 camps, the count of crime events occurring within these camp buffers, and corresponding location quotients.

Table 4. Top 10 campsites associated with highest risk of victimization, based on count of crime events within 349 feet of site

\begin{tabular}{ccccc}
\hline Camp ID & Neighborhood & $\boldsymbol{f}$ (all crime) & LQ (Portland) & LQ (Camps) \\
\hline 6163 & Hazelwood & 431 & 86.6 & 30.4 \\
9361 & Downtown & 310 & 72.3 & 21.9 \\
590 & Old Town & 308 & 61.9 & 21.8 \\
2822 & Old Town & 300 & 60.3 & 21.2 \\
6469 & Old Town & 297 & 59.7 & 21.0 \\
4288 & Old Town & 294 & 59.1 & 20.8 \\
5618 & Downtown & 278 & 55.9 & 19.7 \\
6126 & Old Town & 271 & 54.5 & 19.1 \\
6506 & Downtown & 264 & 53.1 & 18.7 \\
8861 & Downtown & 259 & 52.1 & 18.3 \\
\hline
\end{tabular}

As shown in Table 4, four of the high-risk camps were located in the downtown area and five were located in Old Town, which is a centrally located neighborhood adjacent to downtown. The camp with the highest amount of nearby crimes was in Hazelwood, a neighborhood located around nine miles East of Downtown Portland. This reported camp site had 431 total crime points within a one-block radius. Although one single camp buffer makes up only $0.009 \%$ of the area of Portland, this Hazelwood site contained $0.8 \%$ of the total crimes in Portland. A large majority of crimes at this location were property crimes, only eight were person crimes, and ten were crimes against society. Based on the calculated location quotient, crimes near this camp are 86.6 times more 
concentrated than the city as a whole $(\mathrm{LQ}=86.6)$, and 30.4 times more concentrated than crime in all homeless camp buffers $(\mathrm{LQ}=30.4)$.

At the individual level, statistics were also considered for camps with low levels of nearby crime concentration. A total of 920 reported campsite locations did not have any crimes reported nearby. Another 2,002 camps had only one to four crimes within their buffer areas. As camps with less than five crimes occurring in their buffer areas had a location quotient of less than 1.0 , these findings indicate that $29.7 \%$ of camp locations had less crime concentrated nearby than the average concentration of crime in the city $(n=2,922)$. Further, considering the standard used in this study to measure a meaningful concentration of crime, $47.6 \%$ of camps do not meet this criterion. These 4,683 camp locations had less than 10 crime events occurring within their individual buffers which calculates to location quotients of less than 2.0.

\section{Research Question 2a}

To further understand the risk of crime occurring near high-crime camp locations, individual camp buffers were analyzed by crime category. When using individual buffers to assess the victimization risk at individual camps, results indicate that some camps have considerably higher concentrations of crime than others. Buffer analysis results were used to identify and assess the top ten camp locations at highest risk of society crime, property crime, and person crime victimization. To further explore the spatial relationship between crime and individual camp buffers, location quotients for high-crime camp areas were calculated for each individual camp. These location quotients compared the concentration 
of crime within individual camp buffers to the greater Portland area and to the concentration of crime within all homeless camp buffers in Portland.

Table 5. Top 10 campsites associated with highest risk of property crime victimization, based on count of crime events within 349 feet of site

\begin{tabular}{ccccc}
\hline Camp ID & Neighborhood & $\boldsymbol{f}$ (Property) & LQ (Portland) & LQ (Camps) \\
\hline 6163 & Hazelwood & 413 & 98.1 & 34.8 \\
9361 & Downtown & 257 & 61.1 & 21.7 \\
5618 & Downtown & 239 & 56.8 & 20.2 \\
6506 & Downtown & 227 & 53.9 & 19.1 \\
8861 & Downtown & 224 & 53.2 & 18.9 \\
5464 & Hazelwood & 186 & 44.2 & 15.7 \\
9422 & Hazelwood & 186 & 44.2 & 15.7 \\
6885 & Mill Park & 181 & 43.0 & 15.3 \\
3985 & Woodland Park & 166 & 39.5 & 14.0 \\
4033 & Woodland Park & 166 & 39.5 & 14.0 \\
\hline
\end{tabular}

The top 10 camps at highest risk of property crime were located in Hazelwood, Downtown, Mill Park, and Woodland Park. Table 5 portrays the property crime counts and location quotients for each of the top 10 camps at highest risk of property crime. While overall crime at the highest risk location, camp 6163, was found to be 86.6 times more concentrated than crime in Portland, property crime at this location was 98.1 times more concentrated than property crime in the city. The following four locations, with 224 to 257 crime events occurring within their buffers, were all located in the downtown area. The property crime concentration in these camps ranged from 53.2 to 61.1 times the concentration in the city as a whole and 21.7 to 18.9 times the property crime concentration within all homeless camp buffers. The top five camps at highest risk of 
property crime victimization were also listed within the top 10 camps at high risk of victimization across all crime types.

Table 6. Top 10 campsites associated with highest risk of society crime victimization, based on count of crime events within 349 feet of site

\begin{tabular}{lcccc}
\hline Camp ID & Neighborhood & $\boldsymbol{f}$ (Society) & LQ (Portland) & LQ (Camps) \\
\hline 111 & Old Town & 95 & 427.6 & 99.2 \\
6846 & Old Town & 86 & 387.9 & 90.0 \\
3362 & Old Town & 80 & 360.3 & 83.6 \\
399 & Old Town & 77 & 346.6 & 80.4 \\
1491 & Old Town & 77 & 346.6 & 80.4 \\
193 & Old Town & 76 & 343.1 & 79.6 \\
2430 & Old Town & 76 & 343.1 & 79.6 \\
7259 & Old Town & 69 & 310.3 & 72.0 \\
717 & Old Town & 67 & 301.7 & 70.0 \\
4376 & Old Town & 65 & 293.1 & 68.0 \\
\hline
\end{tabular}

Table 6 portrays the top 10 reported homeless camp sites with the greatest count of society crime events reported nearby. All 10 camps associated with the highest risk of society crime victimization were located in the Old Town area. Location quotients for these camps were substantially higher than society crimes concentrated near other reported camp locations. Society crime near the camp at the highest risk, camp 111, was 427.6 times more concentrated than Portland as a whole and 99.2 times more concentrated than society crime near other reported homeless camp locations. A total of $4.0 \%$ of all society crime events occurred within this camp buffer although the buffer makes up only $0.009 \%$ of the area of Portland. None of the 10 camps at highest risk of society crime were listed in the top 10 for any other crime category, or for overall crime risk. 
Table 7. Top 10 campsites associated with highest risk of person crime victimization, based on count of crime events within 349 feet of site

\begin{tabular}{lcccc}
\hline Camp ID & Neighborhood & $\boldsymbol{f}$ (Person) & LQ (Portland) & LQ (Camps) \\
\hline 2822 & Old Town & 133 & 316.4 & 84.9 \\
6469 & Old Town & 132 & 313.6 & 84.1 \\
590 & Old Town & 124 & 294.5 & 79.0 \\
4288 & Old Town & 123 & 291.8 & 78.3 \\
6126 & Old Town & 111 & 263.6 & 70.7 \\
9759 & Old Town & 106 & 251.8 & 67.6 \\
8554 & Old Town & 93 & 220.9 & 59.3 \\
8700 & Old Town & 90 & 213.6 & 57.3 \\
8534 & Old Town & 63 & 150.0 & 40.2 \\
8901 & Old Town & 63 & 150.0 & 40.2 \\
\hline
\end{tabular}

Similar to high society crime risk camps, the 10 camps at highest risk of person crimes were also located in the Old Town neighborhood. These camps and their corresponding location quotients are listed in Table 7. The camp with the most person crimes occurring within a block radius, and therefore with the highest risk of victimization, had 133 crime events occurring nearby. Person crimes near this camp were found to be 316.4 times more concentrated than person crimes in Portland and 84.9 times more concentrated than person crimes within all homeless camp buffers. Person crime events within a block radius of this location make up $2.8 \%$ of the city's overall person crimes. While the crime locations identified in the high-risk category for person crime are not at high-risk for other crime categories, four of these crimes were also listed as highrisk sites for overall crime (see Table 4). 


\section{Chapter V. Discussion}

The primary purpose of this study was to gain further insight into the potential increased risks of victimization faced by individuals experiencing homelessness in Portland, Oregon. While past studies have examined risk of victimization among homeless communities, the spatial relationship between homeless camps and risk of victimization has not been considered. This study addresses this gap by conducting several spatial analyses which explore the geographic relationship between reported homeless camp locations and reported crime events. Results from this study largely support the research hypotheses, finding that the risk of victimization is concentrated near reported homeless camps as compared to Portland as a whole, and some individual camps have substantially higher risks of victimization than others. This chapter will apply past research and theory to these findings, address limitations to this study, and emphasize the need for future research in these areas.

\section{Research Question 1}

On the macro level, initial analyses indicated that crime was 2.9 times more concentrated within one block of homeless camp locations compared to the city as a whole. As crime concentration was utilized in this study as a proxy for risk of victimization, these results indicate that the risk of victimization near reported homeless camps is almost three times that in the greater Portland area. Further, crime events were found to be disproportionately higher within homeless camp buffers. In total, these buffers cover $14.0 \%$ of the area of Portland, but contain $40.6 \%$ of all crime events. Although this study was unable to identify the residential status of crime victims, this 
spatial relationship aligns with past studies which have consistently found that individuals experiencing homelessness are at higher risk of being victimized (Desai et al., 2002; Edalati et al., 2017; Maniglio, 2009; Teplin et al., 2005).

In assessing this study's findings through a theoretical lens, it is important to understand environmental factors that may contribute to both homeless camp site selection and criminal activity. Crime pattern theory and routine activity theory emphasize that crime is most likely to occur within an offenders' regular travel patterns. As common travel often relies on road networks, crime may be concentrated in these areas. Harrell's (2019) study found that, like crime, homeless camps were concentrated near main streets. Another important consideration in this regard is that the homeless camp data used for this study was limited to citizen reports. Due to this reporting method, there is a possibility that camps are more likely to be reported near main streets because they are more visible to the public in these areas. Even though this study was unable to differentiate between crimes occurring away from road networks, it is worth noting these potential similarities in spatial patterns of crime and homeless camps.

To assess and compare crime concentration in proximity to homeless camps, a multiple ring buffer analysis was applied to camp locations. Based on results from this analysis, crimes were more concentrated within one block of homeless camps as compared to two and three blocks. In other words, crime concentration was found to decrease as distance from camps increased. On the surface, this finding appears to indicate that there is something inherently criminogenic about the areas where homeless camps are located. However, follow up analyses indicate that these results are not true 
across all campsites. These subsequent findings are further explored in the following section. Although this study was unable to identify or focus on the criminogenic characteristics of these areas, past literature offers a couple potential explanations for these findings.

Considering the impact of certain crime types, Lee and Schreck (2005)'s study found that almost $50 \%$ of 2,401 homeless respondents reported a property crime compared to $21.3 \%$ who reported at least one physical assault during their time living on the streets. Applying these results to homeless camps, it was expected that there would be a meaningful relationship between property crimes and homeless camp locations. These expectations were upheld as property crimes were found to be 2.8 times more concentrated near camp locations. Person crime concentration near reported homeless camps, however, was found to be greater than property crime as person crimes in homeless buffers were found to be 3.6 times the concentration of person crimes in Portland as a whole. An important consideration when interpreting the results of person crime is that a considerable proportion of person crimes were excluded from this analysis due to redacted spatial data. Even so, these findings align with past studies that have identified risk of violent victimization to be higher among members of the homeless community (Gaetz et al., 2016).

The crime type with the highest concentration near homeless camps was society crime. As over half of society crimes are drug and narcotic offenses, these findings are also in line with past literature. Although scholars have long considered the relationship between drug use and homelessness, finding that individuals experiencing homelessness 
are more likely to suffer from drug addiction (Huntley, 2015), this current study is unable draw connections between individual information and reported offenses. Instead, findings denote a correlation between the spaces in which society crimes have occurred and homeless camp locations. In this sense, social disorganization in areas near certain homeless camp locations may attract opportunities for crime and therefore cultivate drug activity, similar to findings from Ratcliffe and McCord's (2007) Philadelphia study. Another important consideration regarding these findings is that there may be a relationship between response rates of individuals reporting homeless camps and those reporting drug and narcotic offenses. Of the 7,559 individuals who included additional comments in their homeless camp reports, $10.2 \%(\mathrm{n}=777)$ cited "drugs" as a specific concern and 5.2\% (n=393) included mention of "needles" in their comments. While this study did not assess the location of these camps specifically, this finding indicates that many individuals reporting homeless camps are also concerned with drug activity. Reporting patterns in these areas could be more thoroughly explored in future research to identify possible trends and address potential concerns with the criminalization of the homeless community.

\section{Research Question 2}

Findings from the second phase of this study indicate that some camp locations had substantially higher counts of crime within their buffer areas as compared others. To identify these camp locations, undissolved buffers were applied to camp locations. Highrisk camps were found to be located in three different Portland neighborhoods including Hazelwood, Downtown, and Old Town. Environmental characteristics within these 
camps were not further investigated. Identifying these characteristics to create a typology for camps facing the highest risk of victimization would be a useful next step toward addressing concerns with victimization near homeless camps.

By taking a closer look at crime concentrations near individual camp sites, this study identified high-risk campsites for each crime category. Identifying these high-risk camps is the first step needed to effect positive change for members of the homeless community. Understanding the unique crime profiles in high-risk camp locations allows for resources to be personalized to best meet the risks and needs of individuals living near certain camps. The Navigation Team responsible for assessing all reported camp locations does not currently consider risk or potential risk of victimization in their assessments and reports. By incorporating a spatial element into their risk assessment to identify risk of victimization near camps based on past crime events, this team can better assist those experiencing homelessness and work toward reducing or preventing the impact of victimization. Additionally, identifying these high crime locations can assist with the allocation of resources as those experiencing homelessness in high-risk areas may benefit from outreach and support services.

Based on this study's findings that show how all types of crime are concentrated near homeless camps, this research indicates that outreach programs could benefit from incorporating a measure of victimization risk in their campsite assessments. By identifying certain areas with disproportionately high rates of nearby crime events, city resources can prioritize their humanitarian efforts by allocating resources to individuals who may be at higher risk of victimization. Another important factor to consider when 
incorporating a spatial element in risk assessments used for camp prioritization is the unique crime distributions around camps. Results from this study showed that different categories of crime concentrated in different areas and near different homeless camps. There were no camps found to be at high risk across all crime categories, and, while there was some overlap between overall crime and the person and property categories, the 10 camps with the highest concentration of society crimes were not at high risk in any other category. These findings emphasize the need for individualized assessment and treatment. This is especially important when considering different ways to address various forms of victimization as services needed to reduce society crimes may vary drastically from resources needed to assist victims of person crimes.

Findings from this phase of the study supported the research hypothesis that camps are unique in their surrounding crime concentrations. While some camps have substantially higher concentrations of crime than others, some do not have any nearby crime at all. Considering how $29.7 \%$ of individual camps were found to have a nearby crime concentration less than that of the city, high crime concentrations are not consistent around every reported homeless camp. This accentuates the need for a risk assessment to prioritize camps for service distribution. Also, as these camps are located throughout the city, this highlights the need for individual assessment and consideration of victimization risks at the individual camp level. Taking this a step further, future research could work toward identifying characteristics of high-risk camps in each crime category and incorporate these characteristics into risk assessments for allocating support services and 
other resources. In this way, resources could both account for risks of victimization and be adapted to the unique needs of each reported campsite.

\section{Limitations}

When applying and interpreting the results of this study, it is important to understand all limitations involving the data, measures, interpretation, and application of this research. As with most crime data, crime event datapoints used for this study were based only on reported incidents and may not therefore be reflective of all crimes occurring in the Portland area in 2019. The homeless camp data is also limited in this regard as the dataset only includes camps that have been reported by citizens. Further, using crime concentration as a proxy measure for risk of victimization serves as another limitation to this study. Considering the analytical methods used throughout this research, results were limited to spatial assessments between crime and camp locations and did not include any individual level information regarding the homeless status of those involved in criminal events. Also related to the spatial nature of this research, no causal inferences can be made based on the results from this study. Even with these limitations in mind, results from this study provide a clear baseline for future studies and can contribute to policy changes focusing on prioritizing homeless camp aid based on an additional consideration of risk of victimization.

First, as with most criminological research relying on crime data, this study only considered reported criminal offenses. There is a possibility that crimes are more likely to be reported in certain areas, or by certain people, which may impact this study's findings. Also, because this study relied on reported crime event locations as a proxy measure for 
risk of victimization in these areas, it is important to consider this study's inability to assess unreported criminal activity. By utilizing crime concentration as a proxy measure for risk of victimization, this study was unable to directly assess areas with definitive risks of victimization. Due to this limitation, there is a possibility that past crime concentration rates are not indicative of future risks of victimization, which is an important consideration when interpreting research results. While self-report victimization survey data is typically used to address these concerns, a dataset of this nature was not available for the Portland area at the time of this study. Even though there is not currently a method used to track all crime, reported crime figures still have their value in research. In this case, this study was still able to identify locations at higher risk of victimization and emphasize concerns with high concentrations of reported crime near certain homeless camp locations.

Second, the City of Portland's homeless camp data used for this study was both unique and limited. Due to the nature of this data, accuracy is largely dependent on public reporting. Even so, the HUCIRP Navigation Team visits each reported location to verify that camps are reported in accurate locations. These methods attempt to alleviate concerns with potential inaccurate or repeat reporting. Similar to concerns with crime underreporting, this dataset only includes reported campsite locations and may not therefore reflect all camps in the Portland area. There is a possibility that the homeless camp dataset is limited to campsites visible from public access roads which may lead to possible underreporting concerns. Also, reported homeless camps may not encompass all 
homeless camp locations and may instead focus only on those posing a nuisance or otherwise identified by citizens.

Another consideration regarding the relationship between crime risk and camp locations is that it could be possible that higher crime concentrations near reported homeless camps are a result of reporting patterns. Individuals may be more likely to report crimes in areas where they are likely to report homeless camp locations. Camps and crimes in less visible areas may therefore be more commonly overlooked by reporting parties. To address this concern, future studies can consider the use of survey victimization data to explore whether victimization locations reported in surveys differ from reported crime locations. Even with these limitations in mind, data of this nature is useful as it provides an overview of a substantial amount of camps and crimes which allowed for successful and meaningful analyses.

Third, due to the nature of the analytical methods used in this study, causal inferences between homelessness and crime were not able to be made. Results from this study only indicate that a spatial relationship exists between concentrations of crime, and therefore risk of victimization, and reported homeless camp locations in Portland. By using geographic information, offender and victim characteristics including homeless status were not incorporated into this study. Instead, this study focused on identifying a spatial relationship between homeless camps and crime which indicates a need for future assessment. Methods used in this study were also limited by the fact that environmental characteristics of identified high-risk areas were not closely examined. In order to apply this research to methods used to reduce risk of future victimization, researchers can build 
on this study's findings to further explore potential causal relationships or correlations between the risk of victimization and environmental characteristics of homeless camp locations.

Limitations of this study do not impact the value of the research findings. While significant underreporting may impact the locations of the top 10 identified high-risk camps, this would not take away from the fact that those identified in the study are still at high-risk for victimization. The identification of these high-risk locations is essential when risk of victimization is considered as an element in a campsite risk assessment. Further, as reported crime was found to be more concentrated near homeless camps, these results still accentuate a need for intervention and follow up in these areas. Building on these findings, future research could address limitations of this study by identifying characteristics of high-risk campsites that are unique to other locations, or by conducting survey research to gain a more accurate understanding of all crime occurring in the city.

\section{Future Research Directions}

In consideration of the findings and limitations of this study, there are several opportunities for future research. Working toward an efficient and inclusive risk assessment, taking a closer look at high-risk camps is imperative. This research should include assessments on environmental characteristics of these camp locations to attempt to identify potential criminogenic features in these areas. If consistent information is found, results from this type of study can further guide the development of risk assessments that account for risk of victimization. Further, to account for the needs of those experiencing homelessness at or near camp locations in Portland, individual level 
data should be assessed. By identifying individuals in these areas who have experienced being the victim of a crime, researchers could further understand demographics facing higher risks of victimization which can help further guide their support efforts. Finally, although findings from this study are only relevant to the Portland area, this research accentuates the value of collecting this data and conducting this research in other locales. 


\section{Chapter VI. Conclusion}

Several past studies have considered the relationship between homeless status and risk of victimization, consistently finding that those experiencing homelessness face a higher risk of victimization than the general public (Desai et al., 2002; Edalati et al., 2017; Maniglio, 2009; Teplin et al., 2005). While results from these studies emphasize the need for allocating victimization resources to those experiencing homelessness, they often overlook important geographical elements. Understanding areas with higher risk of victimization is important to implement programs in effective locations and best identify those who may be facing higher risks. Through assessing the spatial patterns of homeless camps and crime in Portland, Oregon, this study contributes to a broader understanding of risks faced by individuals living at or near homeless camps which further highlights the need for effective intervention.

Based on findings from this study, the concentration of criminal events was found to be higher within homeless camp buffers. This indicates that individuals near these camps may face a higher risk of victimization. The highest crime concentrations near homeless camps were found for person and society crimes. The concentration of person crimes was found to be 3.6 times greater near homeless camp locations compared to the city as a whole. Higher concentrations of society and person crime in areas near certain homeless camp locations may contribute to social disorganization and therefore lead to further crime. To address these concerns, prioritization of high-risk camps is necessary. While Portland has several programs in place dedicated to serving marginalized populations, their risk assessments do not currently include an evaluation of victimization 
risk. By using guidance from this study to incorporate an additional measure of victimization risk, local resources can expand their risk assessments to best serve individuals in or around high-risk camp locations. These resources and outreach measures can further be adapted through consideration of the type of victimization risk in different areas.

There are two broad ways in which findings from this study can be applied to best effect positive change for the homeless community. First, this information can be used for support services to identify high-risk locations and target their resources accordingly, based on the unique risks faced by individuals in these locations. By incorporating this information into their risk assessments, the Homeless and Urban Camping Impact Reduction Program (HUCIRP) and Navigation Team can prioritize camps facing the highest risks of victimization. They can further personalize resources according the most prevalent crime risk in the area. Taking this a step further, future research can investigate the concentration of different crime types within the larger crime categories. This would allow for more specific intervention and resource distribution.

Second, findings from this study can be applied to future research to work toward an effective prevention strategy. Based on results from individual campsite analyses, certain reported campsites were found to have substantially higher concentrations of nearby crime than others. This indicates that there is something unique about some homeless camp locations that is impacting risk of victimization. To further understand these findings, future research should draw from past studies to work toward identifying characteristics of these sites. This is the first step toward addressing victimization 
concerns at the source to have a positive impact on future victimization risks. Taking this a step further, researchers could also consider victim information and victim characteristics that may be indicative of increased risks of victimization. Through identifying high-risk characteristics of camps and victims, policies and programs can focus on prevention strategies which consider these specific concerns. 


\section{Chapter VII. References}

A Home for Everyone. (2019). Point-in-time: Count of homelessness in Portland/ Gresham/ Multnomah County, Oregon.

Amster, R. (2008). Lost in space: The criminalization, globalization, and urban ecology of homelessness. New York: LFB Scholarly Publishing.

Barthuly, B. (2019). Spatial Analysis of Burglary and Robbery Crime Concentration Near Mass-Transit in Portland (unpublished master's thesis). Portland State University, Portland, Oregon.

Bernasco, W. \& Block, R. (2011). Robberies in Chicago: A block-level analysis of the influence of crime generators, crime attractors, and offender anchor points. Journal of Research in Crime and Delinquency, 48(1), 33-57.

Borchard, K. (2005). The word on the street: Homeless men in Las Vegas. Reno, Nev.: University of Nevada Press.

Brantingham, P. J., Brantingham, P. L. \& Andresen, M. (2017). The geometry of crime And crime pattern theory [Chapter 5]. In R. Wortley \& M. Townsley (eds.), Environmental criminology and crime analysis (pp. 98-115). New York, NY: Routledge.

Brantingham, P. L. \& Brantingham, P.J. (1995). Criminality of place: Crime generators and crime attractors. European Journal on Criminal Policy and Research, 13(3), $5-26$.

Bursik, R., \& Webb, J. (1982). Community Change and Patterns of Delinquency. American Journal of Sociology, 88(1), 24-42. 
Cahill, M. E. (2004). Geographies of urban crime: An intraurban study of crime in Nashville, Tennessee; Portland, Oregon; and Tucson, Arizona. ProQuest Dissertations and Theses.

Cohen, L. E. \& Felson, M. (1979). Social change and crime rate trends: A route activity approach. American Sociology Review, 44, 588-608.

Cornish, D. B. \& Clarke, R. V. (1975). Residential Treatment and its Effects on Delinquency. Home Office Research Studies 32. London: HMSO.

Davie, M. R. (1937). The pattern of urban growth. Indianapolis, IN: Bobbs-Merrill, College Division.

Dawson, C. A. \& Warner E. Gettys, W. E. (1935) An Introduction to Sociology, Revised edition, 129-156, New York.

Delisi, M. (2000). Who is more dangerous? Comparing the criminality of adult homeless And domiciled jail inmates: A research note. International Journal of Offender Therapy and Comparative Criminology, 44(1), 59-69

Department of Commerce. (2016). Homelessness myths and facts. Retrieved from www.commerce.wa.gov.

Desai, S., Arias, I., Thompson, M. P., \& Basile, K. C. (2002). Childhood victimization And subsequent adult revictimization assessed in a nationally representative sample of women and men. Violence and victims, 17(6), 639.

Donley, A., \& Gualtieri, M. (2017). "Homeless killer": An analysis of the media's portrayal of the victims of a serial killer. Deviant Behavior, 38(2), 226-239.

Edalati, H., Nicholls, T., Crocker, A., Roy, L., Somers, J., \& Patterson, M. (2017). 
Adverse childhood experiences and the risk of criminal justice involvement and victimization among homeless adults with mental illness. Psychiatric Services (Washington, D.C.), 68(12), 1288-1295.

Felson, M. (2017). The routine activity approach [Chapter 4]. In R. Wortley \& M. Townsley (eds.), Environmental criminology and crime analysis (pp. 87-97). New York, NY: Routledge.

Fischer, S., Shinn, M., Shrout, P., \& Tsemberis, S. (2008). Homelessness, mental illness, And criminal activity: Examining patterns over time. American Journal of Community Psychology, 42(3-4), 251-265.

Fitzpatrick, K., \& Myrstol, B. (2011). The jailing of America's homeless: Evaluating the rabble management thesis. Crime \& Delinquency, 57(2), 271-297.

Gaetz, S., O’Grady, B., Kidd, S., \& Schwan, K. (2016). Without a home: The national youth homelessness survey. Toronto: Canadian Observatory on Homelessness Press. Retrieved from https://homelesshub.ca/sites/default/files/attachments/ WithoutAHome-final.pdf

Gerell, M. (2018). Bus stops and violence, are risky places really risky? European Journal on Criminal Policy and Research, 24(4), 351-371.

Groff, E. (2011). Exploring 'near': Characterizing the spatial extent of drinking place Influence on crime. Australian \& New Zealand Journal of Criminology, 44(2), 156-179. https://doi.org/10.1177/0004865811405253

Haggerty, L. (1971). Another look at the Burgess hypothesis: Time as an important variable. American Journal of Sociology, 76(6), 1084-1093. 
Harrell, K. (2019). Homelessness in Portland, Oregon: An analysis of homeless campsite spatial patterns and spatial relationships (unpublished master's thesis). Portland State University, Portland, Oregon.

Henry, M., Mahathey, A., Morrill, T., Robinson, A., Shivji, A., \& Watt, R. (2018). The 2018 annual homeless assessment report (AHAR) to congress. The U.S. Department of Housing and Urban Development, Office of Community Planning and Development.

Henwood, B., Stefancic, A., Petering, R., Schreiber, S., Abrams, C., \& Padgett, D. (2010). Social relationships of dually diagnosed homeless adults following enrollment in housing first or traditional treatment services. Journal of the Society for Social Work and Research, 6(3), 385-406.

Hudson, A.L., Wright, K., Bhattacharya, D., Sinha, K., Nyamathi, A., \& Marfisee, M. (2010). Correlates of adult assault among homeless women. Journal of Health Care for the Poor and Underserved 21(4), 1250-1262.

Huntley, S. (2015). A comparison of substance abuse severity among homeless and non homeless adults. Journal of Human Behavior in the Social Environment, 25(4), $312-321$.

Kim, M., Ford, J., Howard, D., \& Bradford, D. (2010). Assessing trauma, substance abuse, and mental health in a sample of homeless men. Health \& Social Work, 35(1), 39-48.

Kinney, J. B., Brantingham, P. L., Wuschke, K., Kirk, M. G., \& Brantingham, P. J. 
(2008). Crime attractors, generators and detractors: Land use and urban crime opportunities. Built Environment, 34(1), 62-74.

Kubrin, C. E. (2009). Social disorganization theory: Then, now, and in the future. In Handbook on Crime and Deviance (pp. 225-236). Springer, New York, NY.

Kubrin, C., \& Weitzer, R. (2003). New directions in social disorganization theory. Journal of Research in Crime and Delinquency, 40(4), 374-402.

Kushel, M., Evans, J., Perry, S., Robertson, M., \& Moss, A. (2003). No door to lock: victimization among homeless and marginally housed persons. Archives of Internal Medicine, 163(20), 2492-2499.

Lee, B., \& Schreck, C. (2005). Danger on the streets: marginality and victimization among homeless people. American Behavioral Scientist, 48(8), 1055-1081.

Leomporra, A. \& Hustings, M. (2017). Vulnerable to hate: A survey of bias-motivated violence against people experiencing homelessness in 2016-2017. National Coalition for the Homeless.

Maniglio, R. (2009). Severe mental illness and criminal victimization: A systematic review. Acta Psychiatrica Scandinavica, 119(3), 180-191.

McCord, E., \& Ratcliffe, J. (2007). A micro-spatial analysis of the demographic and criminogenic environment of drug markets in Philadelphia. Australian \& New Zealand Journal of Criminology, 40(1), 43-63.

North, C., Smith, E., \& Spitznagel, E. (1994). Violence and the homeless: An epidemiologic study of victimization and aggression. Journal of Traumatic Stress, 7(1), 95-110. 
Nyamathi, A., Leake, B., \& Gelberg, L. (2000). Sheltered versus nonsheltered homeless women: Differences in health, behavior, victimization, and utilization of care. $565-572$.

Park, R. E., \& Burgess, E. W. (1925). The city. Chicago, IL: University of Chicago Press. Portland Police Bureau. (2020a). Metadata for Offense Open Data. Retrieved April 2nd, 2020 from https://www.portlandoregon.gov/police/article/627228

Portland Police Bureau. (2020b). Crime Database. Retrieved February 21st, 2020 from https://www.portlandoregon.gov/police/71978

Quinn, J. A. (1940). The Burgess zonal hypothesis and its critics. American Sociological Review, 5(2), 210-218.

Ratcliffe, J. H. (2012). The spatial extent of criminogenic places: a changepoint regression of violence around bars. Geographical Analysis, 44(4), 302-320.

Regional Land Information System (2020). RLIS Discovery. Portland, OR: Metro Regional Government.

Roy, L., Crocker, A., Nicholls, T., Latimer, E., \& Ayllon, A. (2014). Criminal behavior and victimization among homeless individuals with severe mental illness: A systematic review. Psychiatric Services (Washington, D.C.), 65(6), 739-750.

Schnore, L. (1957). Metropolitan growth and decentralization. American Journal of Sociology, 63(2), 171-180.

Shaw, C. R. and McKay, H. D. (1969). Juvenile Delinquency and Urban Areas. Chicago, IL: The University of Chicago Press.

Snow, D. A., Baker, S. G., \& Anderson, L. (1989). Criminality and homeless men: An 
empirical assessment. Social Problems, 36(5), 532-549.

Snow, D., \& Mulcahy, M. (2001). Space, politics, and the survival strategies of the homeless. American Behavioral Scientist, 45(1), 149-169.

Speiglman, R., \& Green, S. R. (1999). Homeless and nonhomeless arrestees:

Distinctions in prevalence and in socio demographic, drug use, and arrest characteristics across DUF sites. Rockville: National Institute of Justice.

Susser, E., \& Valencia, E. (1997). Preventing recurrent homelessness among mentally ill men: A "critical time" intervention after discharge from a shelter. American Journal of Public Health, 87, 256-263.

Teplin, L. A., McClelland, G. M., Abram, K. M., \& Weiner, D. A. (2005). Crime victimization in adults with severe mental illness: comparison with the national crime victimization survey. Archives of general psychiatry, 62(8), 911-921.

Tessler, R., Rosenheck, R., \& Gamache, G. (2001). Comparison of homeless veterans with other homeless men in a large clinical outreach program. Psychiatric Quarterly, 73,109-119.

The City of Portland. (2019a). Homelessness Toolkit. https://www.portlandoregon.gov/toolkit/article/562211 (last accessed 19 May 2020).

The City of Portland. (2019b). Navigation Team- Portland/ Multnomah County, Oregon. https://www.portlandoregon.gov/toolkit/69845 (last accessed 19 May 2020). The City of Portland. (2019c). Response to homelessness. Issue 7. Retrieved from 
https://www.portlandoregon.gov/toolkit/article/746458 (last accessed 19 May 2020).

Tian, G., Wu, J., \& Yang, Z. (2010). Spatial pattern of urban functions in the Beijing metropolitan region. Habitat International, 34(2), 249-255.

Tsai, J., Lee, C., Byrne, T., Pietrzak, R., \& Southwick, S. (2017). Changes in public attitudes and perceptions about homelessness between 1990 and 2016. American Journal of Community Psychology, 60(3-4), 599-606.

Turner, M., Funge, S., \& Gabbard, W. (2018). Victimization of the homeless: Perceptions, policies, and implications for social work practice. Journal of Social Work in the Global Community, 3(1), 1-12.

United States. Congress. Senate. Committee on the Judiciary. Subcommittee on Crime Drugs. (2011). Crimes against America's homeless: Is the violence growing?: Hearing before the Subcommittee on Crime and Drugs of the Committee on the Judiciary, United States Senate, One Hundred Eleventh Congress, second session, September 29, 2010. (United States. Congress. Senate. S. hrg.; 111-915). Washington: U.S. G.P.O.

Weitzman, B. C., Knickman, J. R., \& Shinn, M. (1992). Predictors of shelter use among low income families: psychiatric history, substance abuse, and victimization. American journal of public health, 82(11), 1547-1550.

Willits, D., Broidy, L., \& Denman, K. (2015). Schools and Drug Markets: Examining the relationship between schools and neighborhood drug crime. Youth \& Society, 47(5), 634-658. 
Wuschke, K., \& Kinney, J. B. (2018). Built environment, land use, and crime. In G. Bruinsma \& S. Johnson (eds.), The Oxford handbook of environmental criminology (pp. 475-496). New York, NY: Oxford University Press. 